\title{
Total Synthesis of Leucascandrolide A: A New Application of the Mukaiyama Aldol-Prins Reaction
}

\author{
Lori J. Van Orden, Brian D. Patterson, and Scott D. Rychnovsky ${ }^{\star}$ \\ Department of Chemistry, 1102 Natural Sciences II, University of California-Irvine, Irvine, California \\ 92697
}

\begin{abstract}
A total synthesis of the marine natural product leucascandrolide A has been completed. The titanium tetrabromide-mediated Mukaiyama aldol-Prins (MAP) reaction with aldehydes developed in our group provided a highly convergent and stereoselective method for assembling the core of the molecule. A new class of MAP reactions with acetals is introduced and mechanistic considerations for both MAP methods are described. The total synthesis was completed by coupling of the side chain through two avenues: A known Still-Gennari olefination and a new $Z$-selective aldol/ dehydroselenation reaction. Both procedures were highly selective and provided the natural product.
\end{abstract}

\section{Introduction}

In 1989, Pietra and coworkers first isolated leucascandrolide A off the coast of New Caledonia from a new genus of calcareous sponges called $L$. caveolata (Figure 1). ${ }^{1}$ Leucascandrolide A has an unusual 18-membered macrolide ring with an alternating oxygenation pattern and a disubstituted oxazole-containing side chain. These structural features are not characteristic of the other metabolites isolated from this class of sponges. ${ }^{2}$ This structurally interesting macrolide is also the most active metabolite isolated from calcareous sponges, with high cytotoxicity in vitro against human $\mathrm{KB}$ tumor cell lines $\left(\mathrm{IC}_{50}=50 \mathrm{ng} / \mathrm{mL}\right)$ and P388 leukemia cell lines $\left(\mathrm{IC}_{50}=250 \mathrm{ng} / \mathrm{mL}\right)$ as well as potent antifungal inhibition against Candida albicans. The biological and medicinal interest in leucascandrolide A prompted unsuccessful attempts to reisolate it and its actual origin is now believed to be from an opportunistic microbial colony. 1

Currently, the only reliable source of leucascandrolide A is through chemical synthesis. In 2000, Leighton reported the first total synthesis, confirming the stereochemical assignments made by Pietra's group. ${ }^{3}$ Since then, there have been elegant total syntheses reported by Paterson, ${ }^{4}$ Kozmin, ${ }^{5}$ and most recently by Panek. ${ }^{6}$ In addition to these projects, many formal syntheses have been reported including ones by Carreira, ${ }^{7}$ Crimmins, ${ }^{8}$ Wipf, ${ }^{9}$ and Williams. 10 Our group also has reported a formal synthesis, which introduced the Mukaiyama aldolPrins (MAP) cyclization as an effective method for generating 2,6-cis tetrahydropyran (THP) rings in complex systems (Scheme 1, top). ${ }^{11}$ The lengthy sequence required to synthesize the requisite enol ether-allylsilane precursor, as well as subsequent elaboration of the core (4) for the completion of the macrocycle, made the overall synthetic strategy inefficient.

Methodology recently developed in our group has shown potential for streamlining the synthesis of the 2,6-cis THP of leucascandrolide A. A titanium tetrabromide-promoted MAP cyclization of simple homoallylic enol ethers and $\alpha$-oxygenated aldehydes was reported to 
provide 2,4,6-cis THP rings with good stereoselectivity (Scheme 1, bottom). ${ }^{12}$ This modified approach allowed accessible cyclization precursors to be used and also afforded more highly functionalized products with three new stereocenters set in a single transformation.

Our new retrosynthetic plan for leucascandrolide A was designed around the new methodology and is detailed below (Figure 2). A cesium carboxylate side chain ${ }^{13}$ displacement of the macrocyclic secondary bromide $\mathbf{8}$ would afford the natural product. A late-stage titanium tetrabromide-promoted MAP cyclization of aldehyde $\mathbf{1 1}$ and one of the homoallylic enol ethers 12 was anticipated to provide the desired 2,4,6-cis THP. The precedent in Scheme 1 suggested that an aldehyde with a chelatable $\alpha$-alkoxy functional group would provide good selectivity at the alcohol center and moderate selectivity for the equatorial bromide in the MAP reaction. Because our proposed aldehyde coupling partner has a $\beta$-alkoxy group from the 2,6-trans THP, we would expect to see results similar to that of the $\alpha$-benzyloxy model system. Enol ethers 12 could be accessed through transvinylations of the corresponding alcohols, which have been previously synthesized by many methods. ${ }^{14}$ The approach envisioned for aldehyde $\mathbf{1 1}$ involved silyl enol ether (14) 4 addition to $\alpha$-acetoxy ether 13 , which would be obtained from a sequence of steps involving a ring closing metathesis of a homoallylic ether $\mathbf{1 5}$ derivative. This alcohol (15) would be accessed from an asymmetric crotylation of the TIPSmonoprotected aldehyde from 1,3-propanediol. ${ }^{15}$

\section{Results}

\section{Synthesis of the MAP Coupling Partners}

The enol ether coupling partners 16a and 16b were accessed in a single step by mercuric trifluoroacetate-catalyzed transvinylation of their corresponding homoallylic alcohols (eq 1). 16 A lower yield is reported for ester-substituted enol ether 16a due to a shorter reaction time, which was necessary to prevent decomposition of the product under the reaction conditions.

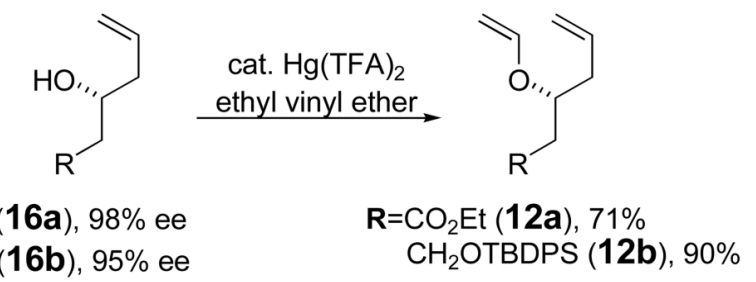

Synthesis of the 2,6-trans THP of leucascandrolide A was initiated from homoallylic alcohol 15. ${ }^{15}$ Acylation with acryloyl chloride provided acrylate $\mathbf{1 7}$, which was subjected to ring closing metathesis (RCM) conditions (Scheme 2). Although there are several protocols for such metatheses, ${ }^{17}$ we were most interested in a recent report by Grubbs of a one-pot tandem $\mathrm{RCM} /$ hydrogenation procedure. ${ }^{18}$ In the first few attempts, the acrylate was subjected to the ruthenium catalyst in one portion $(5 \mathrm{~mol} \%)$ and the solution was heated at reflux for five hours. Following the olefin reduction at $23{ }^{\circ} \mathrm{C}$, lactone 18 was isolated in only $65 \%$ yield along with the reduced acrylate as a major byproduct. Presumably, the ruthenium catalyst was undergoing slow decomposition at elevated temperatures, ${ }^{19}$ leaving unreacted starting material to be reduced in the hydrogenation step. A modification was made to the procedure in which the catalyst was added in two portions. This improved the RCM efficiency to afford $\mathbf{1 8}$ in $91 \%$ yield. Subsequent reductive acetylation, using conditions developed in our group, provided $\alpha$ acetoxy ether $13 .{ }^{20}$ Silyl enol ether $\mathbf{1 4}$, which was synthesized from the corresponding enone, 21 was then coupled with $\mathbf{1 8}$ in the presence of catalytic zinc bromide to generate $\mathbf{1 9}$ in $92 \%$ 
yield. ${ }^{22}$ Axial approach of the nucleophile to the oxocarbenium ion intermediate shown afforded the trans-THP in high diastereoselectivity (20:1). ${ }^{23}$

Based on precedence from Paterson's synthesis of leucascandrolide A, we intended to set the $\mathrm{C} 17$ stereocenter through a regioselective and highly diastereoselective reduction of enone 19. ${ }^{4}$ Formation of either the $(R)$ - or $(S)$-configuration at $\mathrm{C} 17$ would be tolerated as the macrocyclization could proceed with either a Yamaguchi macrolactonization $7,8,10,11$ or Mitsunobu reaction, 4,9 both of which have precedent. Paterson found that $\mathrm{LiHAl}\left(\mathrm{OBu}^{t}\right)_{3}$ reduction of an enone, which is different from 19 only at remote stereocenters, led to the $R$ allylic alcohol with 32:1 stereoselectivity. Applying these reduction conditions to our enone, however, provided primarily ketone $\mathbf{2 2}$ as a result of 1,4-reduction (Table 1, entry 1 ). The selectivity in Paterson's system was attributed to either a highly lithium-coordinated intermediate, which would have directed the reduction through a lowest energy conformation, or an Evans-type polar addition. ${ }^{4}$ Although no modeling studies have been done to investigate the differences between $\mathbf{1 9}$ and Paterson's substrate, it is likely that enhanced lithium chelation was responsible for the reported regioselective and stereoselective hydride addition. Luche reduction conditions and DIBAL-H provided the correct 1,2-regiochemistry for the reduction but offered no stereoselectivity (entries 2 and 3). Corey's oxoborilidine (CBS) catalyst, which is typically used for enantioselective reductions of ketones and enones, ${ }^{24,25}$ showed promise for the diastereoselective reduction of enone 19. Although only starting material was recovered from CBS reductions at $-78{ }^{\circ} \mathrm{C}$ (entry 4), the reaction proceeded smoothly to approximately $75 \%$ conversion at $-45^{\circ} \mathrm{C}$ (entry 5). Increasing the temperature to $0{ }^{\circ} \mathrm{C}$ gave optimal results for the reduction, with the $(R)$-CBS catalyst generating $\mathbf{2 0}$ in an $83 \%$ yield as a single diastereomer (entry 6). The reduction selectivity manifested from the $(S)$-CBS catalyst was inferior, providing a diastereomeric mixture of alcohols favoring $\mathbf{2 1}$ in a ratio of 2.5:1 (entry $7)$.

With all four stereocenters in the C9-C24 fragment of leucascandrolide A established, three additional transformations provided the aldehyde coupling partner for the anticipated MAP cyclization (Scheme 3). Protection of secondary alcohol 20 with triisopropylsilyl trifluoromethanesulfonate (TIPS-OTf) afforded bis-protected diol 23 in quantitative yield. Various conditions were surveyed to achieve selective deprotection of the primary TIPS-ether. Initial attempts utilizing tetrabutylammonium fluoride readily removed both TIPS groups, but a milder $p$-toluenesulfonic acid ( $p$-TsOH)-mediated deprotection was selective. Although subjecting $\mathbf{2 3}$ to stoichiometric $p$-TsOH afforded primarily the bis-deprotected diol, catalytic acid $(20 \mathrm{~mol} \%)$ provided the desired alcohol in reasonable yields $(55-60 \%)$. The recovered bis-protected starting material was recycled to supply an overall yield of 73\%. Aldehyde $\mathbf{1 1}$ was then prepared in $91 \%$ yield by Dess-Martin oxidation.

\section{The Mukaiyama Aldol-Prins Reaction with Aldehydes}

The key MAP reaction between aldehyde 11 and enol ether 12a or 12b was anticipated to provide the 2,4,6-cis THP of leucascandrolide A. Subjection of aldehyde $\mathbf{1 1}$ and enol ether 12a or 12b to cyclization conditions (titanium tetrabromide and 2,6-di-tert-butyl-4methylpyridine (2,6-DBMP)), however, provided undesired adduct 25 as the major product (Table 2, entries 1 and 5). It was presumed that titanium tetrabromide, in addition to mediating the desired MAP reaction, also complexed to and activated the siloxy group, facilitating an allylic displacement by bromide. An aluminum tribromide/trimethyl aluminum mixed Lewis acid system provided similar results (entries 2 and 6). ${ }^{26}$ Attenuation of the titanium tetrabromide with $50 \%$ titanium tetraisopropoxide resulted in only starting materials (entries 3 and 7), but a 9:1 mixture of the two Lewis acids circumvented the side reaction and provided desired products $\mathbf{1 0}$ and $\mathbf{2 4}$, each as a mixture of diastereomers at the alcohol center (entries 4 and 8). 
As shown in the retrosynthetic analysis (Figure 2), enol ether 12a would have been the ideal coupling partner for our key MAP cyclization because the ethyl ester would be at the correct oxidation state for leucascandrolide A. The undesired axial diastereomer, however, was shown to be favored in a 2:1 ratio for this MAP reaction and only modest yields were observed. These results supported those obtained in the segment-coupling Prins reaction: electron withdrawing groups were shown to diminish the yield and to favor axial selectivity for nucleophilic trapping at the $\mathrm{C} 4$ position of the THP. ${ }^{27}$

MAP reactions with the corresponding TBDPS ether $(\mathbf{1 2 b})$ were consistently high yielding $(97 \%)$ and slightly favored the desired equatorial bromide $\mathbf{1 0 b}$. The axial and equatorial bromide adducts (10b and $\mathbf{2 4 b}$ ), which were separable by chromatography, were individually methylated with methyl trifluoromethanesulfonate. The diastereomeric ratios of the methoxy epimers were determined to be approximately 7.8:1 for the axial bromide diastereomer and 4.5:1 for the equatorial bromide diastereomer. Although no studies were done to determine the absolute configuration of the $\mathrm{C} 9$ center, we presumed that the major diastereomers formed (as shown in Table 2) were those that would arise from a preferred 1,3-anti aldol addition (see discussion). ${ }^{28}$ Subsequent spectroscopic correlation with authentic leucascandrolide A substantiated this assumption.

As an interesting observation, tin tetrabromide, which is a popular Lewis acid for initiating Mukaiyama aldol reactions, failed to provide good conversion to the desired products in any of the MAP reactions investigated (eq 2). These conditions afforded acetals $\mathbf{2 6}$ as the major products. MAP reactions require a Lewis acid that can serve as a source of bromide ion to trap the cyclized THP carbenium ion after the initial aldol reaction. If the Lewis acid is not reactive enough or cannot provide a sufficiently nucleophilic bromide source, the intermediate oxocarbenium ion will be trapped with an extra equivalent of aldehyde. Model studies demonstrated that titanium tetrabromide was active enough to convert acetals similar to $\mathbf{2 6}$ to the corresponding Prins products, but that tin tetrabromide was not. 29

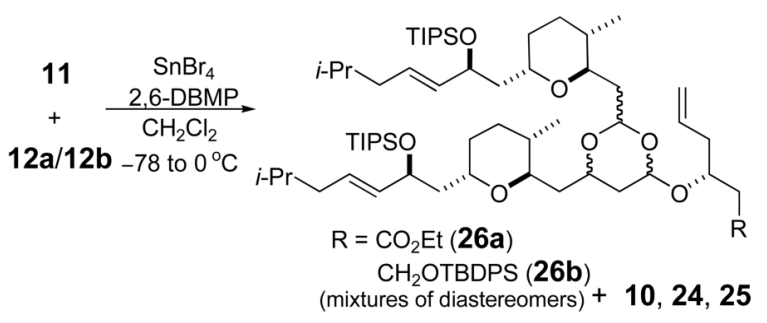

\section{The Mukaiyama Aldol-Prins Reaction with Acetals}

Before continuing on with the proposed synthesis, we decided to investigate the possibility of directly installing the C9 methyl ether through an acetal MAP reaction. Dimethyl acetal 27 was prepared by camphorsulfonic acid-catalyzed acetalization of aldehyde $\mathbf{1 1}$ (Table 3). The titanium tetrabromide/titanium tetraisopropoxide mixed Lewis acid system that was successful for the aldehyde MAP reaction was not optimal in the acetal MAP reaction, providing mainly starting materials (entries 1 and 3). Increasing the equivalents of this mixed Lewis acid (entry 4) or employing titanium tetrabromide alone (entries 2 and 5) afforded quantitative yields of bis-THP 28b for the case of the TBDPS-substituted enol ether 12b and a useful 69\% yield for the ester-substituted enol ether 12a. We presumed that lower yields with 12a could be attributed to an electron withdrawing effect as described earlier. It was surprising that titanium tetrabromide alone led to no observed siloxy displacement, which was prevalent in the aldehyde system with this Lewis acid. The diastereoselectivities from the acetal MAP reaction were also 
different. In the cases where enol ether 12b was employed (entries 4 and 5), the initial aldol reaction into the acetal was completely unselective, but selectivity for the equatorial bromide improved significantly from ca. 1.3:1 to 8.0:1. A rationale for this interesting change in selectivity will be described in the discussion section.

\section{Completion of the Leucascandrolide A Macrocycle}

Although the acetal MAP reaction provided excellent diastereoselectivity at the bromide center with enol ether 12b, the 1:1 mixture at the methoxy center was inseparable and contributed to a lower overall yield of the desired diastereomer, as compared to the aldehyde system. Because of these limitations, we chose to complete the leucascandrolide A macrocycle synthesis from intermediate 10b, the major diastereomer obtained from the aldehyde MAP reaction (Scheme 4). Following methylation of the $\mathrm{C} 9$ alcohol, the TBDPS ether was deprotected under basic conditions to provide primary alcohol $\mathbf{2 9}$. This alcohol could be transformed to the carboxylic acid in two steps by a Dess-Martin oxidation and subsequent Kraus oxidation, 30,31 or more directly by Jones oxidation to provide the acid in one step. The TIPS protecting group was removed with TBAF to provide seco acid $\mathbf{3 0}$ in $80 \%$ yield over two steps. A Mitsunobu reaction with tributylphosphine and diisopropyl azodicarboxylate (DIAD) afforded macrolactone $\mathbf{8}$ in $75 \%$ yield. The use of tributylphosphine was critical to avoid a macrocyclization with retention of configuration or DIAD-trapped products, which were common side reactions with triphenylphosphine. Displacement of the equatorial bromide generated in the MAP reaction with cesium acetate, followed by acetate methanolysis provided macrocyclic alcohol 31 in $60 \%$ yield over the two steps. It is important to note that no elimination was observed during the bromide displacement and the macrocyclic lactone was stable to the acetate cleavage conditions.

\section{Synthesis and Coupling of the Oxazole-Containing Side Chain}

Although the sequence described above constituted a formal synthesis of the natural product, we wanted to further highlight the utility of the equatorial bromide formed in the MAP reaction. A direct displacement of this bromide by the cesium carboxylate derivative of the side chain would complete the total synthesis in one step fewer than completion of the formal synthesis. The twelve-step synthesis of side chain aldehyde $\mathbf{3 3}$ followed Leighton's reported procedure (eq 3). ${ }^{3}$ The final two step sequence, including a Still-Gennari olefination ${ }^{32}$ and hydrolysis to form carboxylic acid $\mathbf{3 4}$, was achieved through the procedure of Kozmin. 5

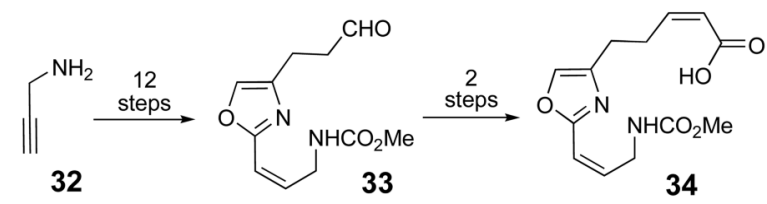

The in situ formation of nucleophilic cesium carboxylates from cesium carbonate and their subsequent displacement reactions are well precedented. ${ }^{33} \mathrm{We}$ anticipated that the addition of cesium carbonate to side chain acid 34, 18-crown- 6 , and macrocyclic bromide 8 would generate leucascandrolide A in a single step. Unfortunately, elimination product $\mathbf{3 6}$ and an olefin isomer of leucascandrolide A (35) were formed in a 1:1 mixture (eq 4). While $\mathbf{3 6}$ may have arisen from an excess of basic cesium carbonate in solution, it was presumed that the $Z$ to $E$ isomerization of $\mathbf{3 5}$ occurred by an addition/elimination of a cesium carboxylate nucleophile or a transient radical. 


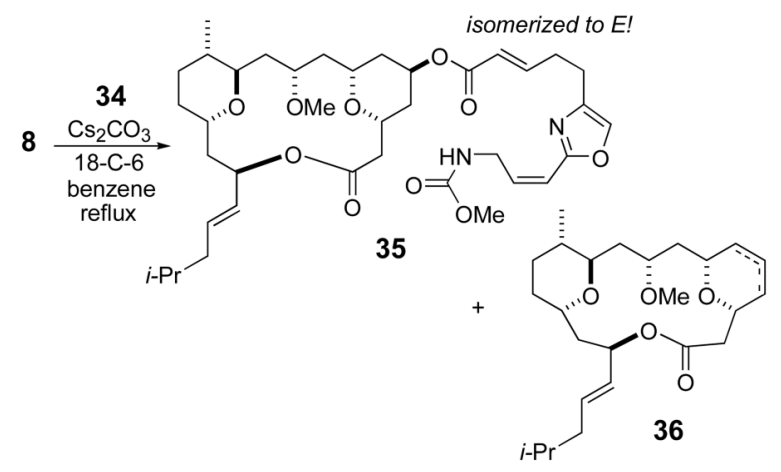

Model bromide 37 and macrocycle 8 were used to identify alternative nucleophiles that could be used in the displacement reaction and be further derivatized in the real system to give the natural product (Table 4). Isolated $\beta$-phosphono-cesium carboxylate $\mathbf{4 2}$ or the corresponding carboxylic acid underwent decomposition in the harsh reaction conditions ${ }^{34}$ (entries 5 and 6 ) and cesium 2-butynoate (43) or its corresponding acid (entries 7 and 8) failed to displace the bromide. An examination of the approximate $\mathrm{pKa}$ values of each of these acids provided insight into the displacement reaction. Cesium acetate (40) and an alkenyl cesium carboxylate with pKa values ca. 4.70 served as effective coupling partners (entries 1 and 2), but compounds with lower pKa values were not effective.

Cesium 2-(phenylselanyl)acetate (41) was shown to be an effective coupling partner on both the model system and macrocyclic bromide $\mathbf{8}$ (Table 4, entries 3 and 4). Utilizing methodology discovered by Toru, ${ }^{35}$ the oxazole-containing side chain could then be attached through a $s y n$-selective aldol reaction and stereospecific dehydroselenation to afford the Z-olefin and leucascandrolide $\mathrm{A}$ in an unoptimized $40 \%$ yield over the two steps (Scheme 5). ${ }^{36}$ To confirm the structure of synthetic leucascandrolide A prepared by this method, the total synthesis was also completed by Leighton's two step procedure, which included acylation of macrocyclic alcohol 31 and a subsequent Still-Gennari olefination reaction. ${ }^{3}$

\section{Discussion}

Recent studies with the segment coupling Prins reaction has provided insight into the stereoselectivity of the MAP process. Because of the disparity in diastereoselectivities derived from the aldehyde and acetal MAP reactions, they will be discussed separately. For $\beta$-alkoxy aldehydes, an initial coordination of titanium tetrabromide would provide intermediate $\mathbf{4 5}$, which has been activated towards the nucleophilic attack of $\mathbf{1 2 b}$ (Scheme 6). This coordination would be expected to favor 1,3-anti attack through six-membered transition state $\mathbf{C}$ (see Figure 3 , left) and this model is consistent with the reaction outcome. Additionally, $\beta$-alkoxy aldehydes have been described by Evans to favor a lowest-energy polarized transition state $\mathbf{A}$, which also results in 1,3-anti aldol products upon the addition of a nucleophile. ${ }^{28}$ Because of the use of a titanium Lewis acid in our system, it is most likely that the addition is controlled by the classic chelation model.

The expected intermediate bromo ether $\mathbf{4 6}$ would engage in the Prins cyclization upon activation by a Lewis acid. ${ }^{37}$ Interaction of $\mathbf{4 6}$ and titanium tetrabromide would generate the contact ion pair 48. Cyclization to the THP cation as modeled by Alder, 38 and direct collapse of this ion pair would favor the axial 4-bromo THP 24b through a least-motion pathway. This outcome is similar to what we have observed for the bromotrimethylsilane induced Prins cyclization. ${ }^{39}$ Alternatively, if the reaction of the ion pair were slow, the contact ion pair would form a solvent separated ion pair $\mathbf{4 9}$, and this intermediate would cyclize to form the equatorial 
4-bromo THP 10b preferentially, based on the preferred orbital alignment present in the tetrahydropyran cation. ${ }^{38}$ The key partitioning event takes place at the contact ion pair $\mathbf{4 8}$. We postulate that the chelated titanium oxocarbenium ion $\mathbf{4 8}$ is more reactive than a typical oxocarbenium ion. High reactivity of the electrophile would favor a fast collapse and lead to axial product. Lower reactivity would allow the ions to separate, and ultimately lead to the equatorial product. Neither pathway is expected to be completely selective. The underlying reasons for greater reactivity of the titanium chelated oxocarbenium ion $\mathbf{4 8}$ are not obvious.

For the acetal case, a slightly modified mechanistic scheme was proposed (Scheme 7). Initial coordination of titanium tetrabromide would provide intermediate $\mathbf{5 0}$, which decomposes to oxocarbenium ion $\mathbf{5 1}$ and the methoxy-titanium tetrabromide "ate" complex shown. A chelation-controlled nucleophilic addition to $\mathbf{5 1}$ is no longer possible, and because a 1:1 mixture of methoxy diastereomers was observed for this addition, it can be assumed that neither of the polar transition states $\mathbf{D}$ or $\mathbf{E}$ (Figure 3) was preferred. Ward also reported lower stereoselectivity for the aldol addition of an allylsilane to a $\beta$-alkoxy acetal (ca. 1:1) as compared to the corresponding aldehyde (>9:1), but offered no explanation of these results.

40 The Mukaiyama aldol reaction with $\mathbf{1 2 b}$ would generate bromo ether intermediate $\mathbf{5 2}$. In this case the active Lewis acid in the system is either titanium tetrabromide or titanium tribromomethoxide. Activation with these Lewis acids would lead to contact ion pair $\mathbf{5 3}$ (or the $\mathrm{TiBr}_{5}{ }^{-}$analogue). As discussed above, direct collapse of this contact ion pair would favor the axial product $\mathbf{5 5}$, and formation of a solvent separated ion pair $\mathbf{5 4}$ would favor the equatorial product 28b. In this case the oxocarbenium ion $\mathbf{5 3}$ shows the expected Prins reactivity, and most of the material passes through the solvent separated ion pair 54 en route to the equatorial 4-bromo THP 28b. We attribute the difference in selectivity between the aldehyde and acetal substrates to the higher reactivity of the aldehyde-derived contact ion pair $\mathbf{4 8}$ compared with 53.

Recall that the unusual preference for an axial 4-bromo Prins adduct does not correlate with the Mukaiyama aldol-Prins reaction or even the use of $\alpha$ - or $\beta$-alkoxy aldehydes. The axial selectivity is found with $\alpha$ - or $\beta$-alkoxy aldehydes that are expected to chelate effectively, such as benzyl ethers, and it not observed with non-chelating alkoxy groups such as TBS ethers.

12 The model that we propose here is based on the unusual reactivity of the titanium-chelated oxocarbenium ion $\mathbf{4 8}$ and is consistent with the observed higher axial selectivity for fastcollapsing ion pairs. 39,41

Scheme 7 also provides an explanation for the absence of solvolysis of the allyl siloxy group without titanium tetraisopropoxide attenuation of titanium tetrabromide. During the formation of oxocarbenium ion 46, one equivalent of methoxide ion was dissociated from $\mathbf{4 6}$, thus forming the attenuated Lewis acid $\mathrm{MeOTiBr}_{3}$ in situ.

\section{Conclusion}

A total synthesis of the structurally complex marine natural product leucascandrolide A has been completed. The synthesis required 17 steps for the longest linear sequence from known alcohol 15 with an overall yield of $4.3 \%$. The MAP reaction with aldehyde 11 was demonstrated to be a highly efficient and diastereoselective process in forming the core of the molecule. The MAP reaction with acetals was also introduced in this synthesis as a method for installing methyl ethers and obtaining high diastereoselectivity for a tetrahydropyranyl equatorial bromide. Studies of this key step led us to formulate mechanistic rationales for both classes of MAP reactions, which led to a better understanding of the origins of diastereoselectivity. Furthermore, this synthesis is the first application of Toru's two-step $Z$-selective olefination on a complex molecule and highlights it as a new method for the installation of the leucascandrolide A side chain unit. 


\section{Experimental Section}

General experimental details, experimental data for all intermediates, and spectra for key intermediates and leucascandrolide A can be found in the supporting information.

\section{Lactone 18}

To a solution of acrylate $17(0.76 \mathrm{~g}, 2.2 \mathrm{mmol}, 1.0$ equiv) in anhydrous, degassed 1,2dichloroethane $(45 \mathrm{~mL})$ was added Grubbs' 2 nd generation ruthenium catalyst ${ }^{42}(47.0 \mathrm{mg}$, $0.056 \mathrm{mmol}, 0.03$ equiv). The solution was heated at reflux for two hours then another equal portion of the catalyst $(47.0 \mathrm{mg}, 0.056 \mathrm{mmol}, 0.03$ equiv) was added. After heating at reflux for an additional $90 \mathrm{~min}$, the dark brown solution was allowed to cool to $23^{\circ} \mathrm{C}$. The open reaction vessel was quickly transferred to a Parr bomb, which was then pressurized with hydrogen gas (100 psi), and stirred vigorously for $16 \mathrm{~h}$. The reaction mixture was then concentrated in vacuo and purified by flash chromatography (10-40\% diethyl ether/hexanes) to afford $0.64 \mathrm{~g}(91 \%)$ of $\mathbf{1 8}$ as a clear, colorless oil: $[\alpha]^{22} \mathrm{D}+63.7(c=1.00$, chloroform); IR (neat) $2943,2868,1742,1094 \mathrm{~cm}^{-1} ;{ }^{1} \mathrm{H}$ NMR $\left(500 \mathrm{MHz}, \mathrm{CDCl}_{3}\right) \delta 4.16(\operatorname{td}, J=10.4,2.4$, $1 \mathrm{H}$ ), 3.94-3.84 (m, 2H), 2.61 (ddd, $J=17.7,6.8,4.8,1 \mathrm{H}$ ), 2.47 (ddd, $J=17.7,9.6,6.0,1 \mathrm{H}$ ), 1.95 (dddd, $J=14.5,8.6,6.3,2.4,1 \mathrm{H}), 1.92$ (ddt, $J=13.4,6.9,4.8,1 \mathrm{H}), 1.82-1.70(\mathrm{~m}, 2 \mathrm{H})$, $1.61-1.52(\mathrm{~m}, 1 \mathrm{H}), 1.07-1.03(\mathrm{~m}, 24 \mathrm{H}) ;{ }^{13} \mathrm{C} \mathrm{NMR}\left(125 \mathrm{MHz}, \mathrm{CDCl}_{3}\right) \delta 171.9,82.9,59.1$, 37.1, 32.7, 29.7, 28.0, 18.2, 17.7, 12.1; HRMS (EI), calcd for $\mathrm{C}_{14} \mathrm{H}_{27} \mathrm{O}_{3} \mathrm{Si}[\mathrm{M}-i \operatorname{Pr}]^{+}$271.1729, found 271.1733 .

\section{Tetrahydropyran 19}

To a solution of acetoxy ether 13 ( $0.62 \mathrm{~g}, 1.79 \mathrm{mmol}, 1.0$ equiv) and silyl enol ether 14 ( 0.71 $\mathrm{g}, 3.58 \mathrm{mmol}, 2.0$ equiv) in anhydrous dichloromethane $(18 \mathrm{~mL})$ was added zinc bromide (40.0 $\mathrm{mg}, 0.179 \mathrm{mmol}, 0.1$ equiv). The slurry was stirred for four hours, then was concentrated in vacuo and immediately purified by flash chromatography (0-7\% diethyl ether/hexanes) to give $0.70 \mathrm{~g}(92 \%)$ of $\mathbf{1 9}$ as a clear, colorless oil with a 2,6-trans/cis diastereomeric ratio of $>95: 5$ (as determined by crude proton NMR spectroscopy): $[\alpha]^{23} \mathrm{D}+35.5$ (chloroform, $c=1.00$ ); IR (neat) $2956,1673,1629,1463,1092,883 \mathrm{~cm}^{-1} ;{ }^{1} \mathrm{H}$ NMR $\left(500 \mathrm{MHz}, \mathrm{C}_{6} \mathrm{D}_{6}\right) \delta 6.72(\mathrm{dt}, J=$ $15.8,7.4,1 \mathrm{H}$ ), 6.04 (td, $J=15.8,1.4,1 \mathrm{H}$ ), 4.39 (app. q, $J=6.1,1 \mathrm{H}$ ), 3.90 (ddd, $J=7.7,6.4$, 2.6, 2H), $3.54(\mathrm{ddd}, J=9.6,6.4,3.3,1 \mathrm{H}), 2.83(\mathrm{dd}, J=15.0,7.1,1 \mathrm{H}), 2.43(\mathrm{dd}, J=15.0,6.4$, $1 \mathrm{H}), 1.95-1.87(\mathrm{~m}, 1 \mathrm{H}), 1.80(\mathrm{td}, J=7.5,3.3,1 \mathrm{H}), 1.77(\mathrm{td}, J=6.8,1.4,2 \mathrm{H}), 1.56-1.36(\mathrm{~m}$, $4 \mathrm{H}), 1.34-1.26(\mathrm{~m}, 1 \mathrm{H}), 1.14-1.18(\mathrm{~m}, 24 \mathrm{H}), 0.88(\mathrm{~d}, J=6.8,3 \mathrm{H}), 0.75(\mathrm{~d}, J=6.7,6 \mathrm{H}) ;{ }^{13} \mathrm{C}$ NMR (125 MHz, $\left.\mathrm{C}_{6} \mathrm{D}_{6}\right) \delta 195.9,145.3,132.1,74.1,67.9,60.8,44.3,41.7,36.3,33.6,28.1$, 28.0, 26.8, 22.4, 18.5, 18.4, 12.4; HRMS (EI), calcd for $\mathrm{C}_{22} \mathrm{H}_{41} \mathrm{O}_{3} \mathrm{Si}[\mathrm{M}-i \mathrm{Pr}]^{+} 381.2825$, found 381.2834; Anal. calcd for $\mathrm{C}_{25} \mathrm{H}_{48} \mathrm{O}_{3} \mathrm{Si}$ : C, 70.70; H, 11.39. Found: C, 70.90; H, 11.33.

\section{Aldehyde 11}

To a solution of the primary alcohol from $\mathbf{2 3}(50.0 \mathrm{mg}, 0.117 \mathrm{mmol}, 1.0$ equiv) in anhydrous dichloromethane $(3 \mathrm{~mL})$ were added pyridine $(40.0 \mu \mathrm{L}, 0.492 \mathrm{mmol}, 4.2$ equiv), followed by Dess-Martin periodinane ( $99.0 \mathrm{mg}, 0.234 \mathrm{mmol}, 2.0$ equiv). This mixture was stirred for two hours then diluted with diethyl ether $(10 \mathrm{~mL})$. A 1:1 mixture of saturated aqueous sodium bicarbonate and saturated aqueous sodium bisulfite $(5 \mathrm{~mL})$ was added and the resultant biphasic mixture was stirred for five minutes. The layers were separated, and the aqueous layer was extracted with diethyl ether $(3 \times 20 \mathrm{~mL})$. The combined organic layers were washed with saturated aqueous sodium bicarbonate $(1 \times 20 \mathrm{~mL})$ and brine $(1 \times 20 \mathrm{~mL})$, dried over anhydrous sodium sulfate, and concentrated in vacuo. The crude oil was purified by flash chromatography on deactivated silica gel ( $1 \%$ triethylamine in the desired eluant) (5-60\% diethyl ether/hexanes) to provide $45 \mathrm{mg}$ (91\%) of $\mathbf{1 1}$ as a clear, colorless oil: $[\alpha]^{23} \mathrm{D}+35.3(c=0.90$, chloroform); IR (neat) 2931, 2718, 1731, $1094 \mathrm{~cm}^{-1} ;{ }^{1} \mathrm{H}$ NMR $\left(500 \mathrm{MHz}, \mathrm{CDCl}_{3}\right) \delta 9.79(\mathrm{dd}, J=3.4,2.0,1 \mathrm{H})$, $5.53(\mathrm{dt}, J=14.9,7.1,1 \mathrm{H}), 5.38(\mathrm{dd}, J=15.4,7.6,1 \mathrm{H}), 4.25(\mathrm{td}, J=8.1,4.6,1 \mathrm{H}), 3.93(\mathrm{dq}$, 
$J=9.3,4.9,1 \mathrm{H}), 3.80(\mathrm{ddd}, J=12.5,8.6,3.9,1 \mathrm{H}), 2.58(\mathrm{ddd}, J=15.7,3.8,2.0,1 \mathrm{H}), 2.49$

$(\mathrm{ddd}, J=15.4,8.8,3.2,1 \mathrm{H}), 2.20(\mathrm{ddd}, J=13.9,9.5,4.6,1 \mathrm{H}), 1.96-1.86(\mathrm{~m}, 2 \mathrm{H}), 1.82-1.73$ $(\mathrm{m}, 1 \mathrm{H}), 1.67-1.58(\mathrm{~m}, 2 \mathrm{H}), 1.54-1.35(\mathrm{~m}, 4 \mathrm{H}), 1.09-1.03(\mathrm{~m}, 21 \mathrm{H}), 0.93-0.86(\mathrm{~m}$, $9 \mathrm{H}) ;{ }^{13} \mathrm{C} \mathrm{NMR}\left(125 \mathrm{MHz}, \mathrm{CDCl}_{3}\right) \delta 202.2,134.2,130.5,72.0,71.7,69.3,47.6,41.8,40.2$, 35.1, 28.9, 28.6, 27.2, 22.7, 22.5, 18.3, 12.6. HRMS (ESI), calcd for $\mathrm{C}_{25} \mathrm{H}_{48} \mathrm{O}_{3} \mathrm{SiNa}[\mathrm{M}+$ $\mathrm{Na}]^{+}$447.3271, found 447.3279. Anal. calcd for $\mathrm{C}_{25} \mathrm{H}_{48} \mathrm{O}_{3} \mathrm{Si}$ : C, 70.70; H, 11.39. Found: $\mathrm{C}$, $70.56 ; \mathrm{H}, 11.45$.

\section{(R)-3-(Vinyloxy)hex-5-enyloxy-tert-butyldiphenylsilane (12b)}

To a solution of secondary alcohol $\mathbf{1 6 b}(2.00 \mathrm{~g}, 5.64 \mathrm{mmol}, 1.0$ equiv) in ethyl vinyl ether (30.0 $\mathrm{mL}$ ) was added mercuric trifluoroacetate $(241 \mathrm{mg}, 0.564 \mathrm{mmol}, 0.10$ equiv). This mixture was allowed to stir in a capped vessel for $48 \mathrm{~h}$. The mixture was then diluted with diethyl ether (75 $\mathrm{mL}$ ) and the layers were separated. The organic layer was washed with saturated aqueous sodium bicarbonate $(50 \mathrm{~mL})$ and brine $(50 \mathrm{~mL})$, dried over anhydrous sodium sulfate, and concentrated in vacuo. The crude oil was immediately purified by flash chromatography on deactivated silica gel (1\% triethylamine in the desired eluant) (0-10\% diethyl ether/hexanes) to provide $1.93 \mathrm{~g}(90 \%)$ of $\mathbf{1 2 b}$ as a clear, colorless oil: $[\alpha]^{23} \mathrm{D}-9.26(c=2.00$, dichloromethane); IR (neat) 3072, 2931, 2858, 1636, $1112 \mathrm{~cm}^{-1} ;{ }_{1}^{1} \mathrm{H}$ NMR (500 MHz, $\left.\mathrm{CDCl}_{3}\right) \delta 7.76-7.68(\mathrm{~m}, 4 \mathrm{H}), 7.50-7.41(\mathrm{~m}, 6 \mathrm{H}), 6.37(\mathrm{dd}, J=14.1,6.6,1 \mathrm{H}), 5.84$ (ddt, $J=$ $16.9,14.1,7.0,1 \mathrm{H}), 5.14(\mathrm{~d}, J=4.1,1 \mathrm{H}), 5.11(\mathrm{~s}, 1 \mathrm{H}), 4.36(\mathrm{dd}, J=14.1,1.4,1 \mathrm{H}), 4.22-4.13$ (m, 1H), 4.03 (dd, $J=6.6,1.4,1 \mathrm{H}), 3.83(\mathrm{dt}, J=13.2,6.7,1 \mathrm{H}), 3.75(\mathrm{dt}, J=10.7,5.4,1 \mathrm{H})$, $2.42-2.35(\mathrm{~m}, 2 \mathrm{H}), 1.88-1.79(\mathrm{~m}, 2 \mathrm{H}), 1.10(\mathrm{~s}, 9 \mathrm{H}) ;{ }^{13} \mathrm{C} \mathrm{NMR}\left(100 \mathrm{MHz}, \mathrm{CDCl}_{3}\right) \delta$ 151.6, $135.8,134.2,133.9,129.8,127.9,117.7,88.3,76.2,60.2,38.8,36.9,27.1,19.4$. HRMS (ESI), calcd for $\mathrm{C}_{24} \mathrm{H}_{36} \mathrm{O}_{2} \mathrm{SiN}\left[\mathrm{M}+\mathrm{NH}_{4}\right]^{+} 398.2515$, found 398.2498. Anal. calcd for $\mathrm{C}_{24} \mathrm{H}_{32} \mathrm{O}_{2} \mathrm{Si}$ : C, 75.74; H, 8.47. Found: C, 75.90; H, 8.51.

\section{MAP products $10 \mathrm{~b}$ and $24 \mathrm{~b}$}

Aldehyde 11 (62.2 mg, $0.146 \mathrm{mmol}, 1.0$ equiv), enol ether 12b $(55.7 \mathrm{mg}, 0.146 \mathrm{mmol}, 1.0$ equiv), and 2,6-di-tert-butyl-4-methylpyridine $(45.0 \mathrm{mg}, 0.219 \mathrm{mmol}, 1.5$ equiv) were dissolved in anhydrous dichloromethane $(6.0 \mathrm{~mL})$. This solution was cooled to $-78{ }^{\circ} \mathrm{C}$ and a 9:1 titanium tetrabromide/titanium tetraisopropoxide Lewis acid blend ${ }^{43}$ as a solution in dichloromethane $(0.78 \mathrm{~mL}, 0.298 \mathrm{mmol}, 0.34 \mathrm{M}, 2.0$ equiv) was added dropwise. After two hours, a 1:1 mixture of methanol and triethylamine $(6 \mathrm{~mL})$ was added dropwise, followed by the addition of saturated aqueous sodium bicarbonate $(2 \mathrm{~mL})$. The biphasic mixture was allowed to warm to $23^{\circ} \mathrm{C}$ and was diluted with diethyl ether $(10 \mathrm{~mL})$. The layers were separated and the aqueous layer was extracted with diethyl ether $(3 \times 10 \mathrm{~mL})$. The combined organic layers were washed with saturated aqueous sodium bicarbonate $(1 \times 10 \mathrm{~mL})$, water $(1 \times 10$ $\mathrm{mL})$, and brine $(1 \times 10 \mathrm{~mL})$, dried over anhydrous sodium sulfate, and concentrated in vacuo. The crude oil was purified by flash chromatography (0-100\% diethyl ether/hexanes) to yield $68.0 \mathrm{mg}(53 \%)$ of $\mathbf{1 0 b}$ as a $4.5: 1$ mixture of diastereomers at the alcohol center and 57 $\mathrm{mg}(44 \%)$ of $\mathbf{2 4 b}$ as a 7.8:1 mixture of diastereomers at the alcohol center: 10b: $[\alpha]_{\mathrm{D}}{ }^{23}+21.9$ ( $c=1.15$, dichloromethane); IR (thin film) 3515, 2952, 2930, 2865, $1111 \mathrm{~cm}^{-1} ;{ }^{1} \mathrm{H}$ NMR (500 $\left.\mathrm{MHz}, \mathrm{CDCl}_{3}\right) \delta 7.65(\mathrm{~d}, J=6.4,4 \mathrm{H}), 7.46-7.36(\mathrm{~m}, 6 \mathrm{H}), 5.56(\mathrm{dt}, J=14.5,7.0,1 \mathrm{H}), 5.41(\mathrm{dd}$, $J=15.5,7.3,1 \mathrm{H}), 4.29$ (app. q, $J=8.4,1 \mathrm{H}), 4.10(\mathrm{tt}, J=10.1,5.0,1 \mathrm{H}), 4.06-3.95(\mathrm{~m}, 2 \mathrm{H})$, 3.77 (dtd, $J=11.5,5.4,1.2,1 \mathrm{H}), 3.71(\mathrm{dt}, J=10.6,5.8,1 \mathrm{H}), 3.67(\mathrm{~d}, J=1.6,1 \mathrm{H}), 3.60-3.42$ (m, 2H), 2.29-2.13 (m, 3H), 1.97-1.86 (m, 2H), 1.86-1.25 (m, 16H), 1.13-1.00 (m, 30H), $0.92-0.87(\mathrm{~m}, 6 \mathrm{H}), 0.85(\mathrm{~d}, J=6.5,3 \mathrm{H}) ;{ }^{13} \mathrm{C} \mathrm{NMR}\left(125 \mathrm{MHz}, \mathrm{CDCl}_{3}\right) \delta 136.0,135.8,135.7$, 135.5, 134.5, 133.9, 133.8, 130.1, 129.9, 127.9, 75.1, 75.0, 73.6, 71.7, 71.6, 69.3, 67.1, 60.2, 45.5, 43.5, 43.3, 41.8, 40.0, 39.9, 38.9, 34.5, 29.1, 28.6, 27.5, 27.1, 22.7, 22.5, 19.4, 18.5, 18.4, 12.6; HRMS (ESI), calcd for $\mathrm{C}_{49} \mathrm{H}_{81} \mathrm{BrO}_{5} \mathrm{Si}_{2} \mathrm{Na}[\mathrm{M}+\mathrm{Na}]^{+}$907.4703, found 907.4703. Anal. calcd for $\mathrm{C}_{49} \mathrm{H}_{89} \mathrm{O}_{5} \mathrm{Si}_{2} \mathrm{Br}$ : C, 66.41; H, 9.21. Found: C, 66.60; H, 9.44. 
24b: $[\alpha]_{\mathrm{D}}^{23}+20.9(c=2.15$, dichloromethane); IR (thin film) 3518, 2952, 2930, 2865, 1095 $\mathrm{cm}^{-1},{ }^{1} \mathrm{H}$ NMR $\left(500 \mathrm{MHz}, \mathrm{CDCl}_{3}\right) \delta 7.79-7.63(\mathrm{~m}, 4 \mathrm{H}), 7.48-7.37(\mathrm{~m}, 6 \mathrm{H}), 5.57(\mathrm{dt}, J=15.0$, $7.1,1 \mathrm{H}), 5.42(\mathrm{dd}, J=15.4,7.4,1 \mathrm{H}), 4.71(\mathrm{t}, J=2.8,1 \mathrm{H}), 4.32(\mathrm{dd}, J=12.9,7.7,1 \mathrm{H}), 4.22$ $-4.06(\mathrm{~m}, 3 \mathrm{H}), 4.02-3.93(\mathrm{~m}, 1 \mathrm{H}), 3.82-3.71(\mathrm{~m}, 2 \mathrm{H}), 3.54-3.48(\mathrm{~m}, 1 \mathrm{H}), 2.18(\mathrm{ddd}, J=13.8$, $8.8,5.1,1 \mathrm{H}), 2.05(\mathrm{dd}, J=12.6,1.7,1 \mathrm{H}), 2.00-1.83(\mathrm{~m}, 5 \mathrm{H}), 1.81-1.27(\mathrm{~m}, 14 \mathrm{H}), 1.19-1.00$ $(\mathrm{m}, 30 \mathrm{H}), 0.95-0.87(\mathrm{~m}, 6 \mathrm{H}), 0.87(\mathrm{~d}, J=6.4,3 \mathrm{H}) ;{ }^{13} \mathrm{C} \mathrm{NMR}\left(125 \mathrm{MHz}, \mathrm{CDCl}_{3}\right) \delta 136.0$, $135.8,135.7,135.5,134.5,134.0,133.9,130.1,129.8,127.9,73.4,72.6,71.6,70.0,69.9,69.2$, $67.8,60.4,50.2,50.1,43.2,41.8,40.3,39.3,38.5,34.7,29.0,28.6,27.5,27.1,22.7,22.5,19.4$, 18.5, 18.4, 12.6; HRMS (ESI), calcd for $\mathrm{C}_{49} \mathrm{H}_{81} \mathrm{BrO}_{5} \mathrm{Si}_{2} \mathrm{Na}[\mathrm{M}+\mathrm{Na}]^{+} 907.4703$, found 907.4714 .

\section{Macrocyclic bromide 8}

To a solution of tributylphosphine $(0.40 \mathrm{~mL}, 1.59 \mathrm{mmol}, 5.0$ equiv $)$ in degassed, anhydrous toluene $(55 \mathrm{~mL})$ was added neat diisopropyl azodicarboxylate $(0.26 \mathrm{~mL}, 1.33 \mathrm{mmol}, 4.2$ equiv). Seco acid 30 (170 mg, $0.318 \mathrm{mmol}, 1.0$ equiv) was then added as a solution in degassed, anhydrous toluene $(11 \mathrm{~mL})$. After $50 \mathrm{~min}$, the mixture was concentrated in vacuo and the crude oil was purified by flash chromatography (0-50\% diethyl ether/hexanes) to provide $119 \mathrm{mg}$ (75\%) of macrocyclic bromide 8 as a white solid: $[\alpha]^{23} \mathrm{D}+49.45(c=0.62$, chloroform); IR (thin film) 2955, 2925, 2854, 1732, $1088 \mathrm{~cm}^{-1} ;{ }^{1} \mathrm{H}$ NMR (600 MHz, $\left.\mathrm{CDCl}_{3}\right) \delta 5.71(\mathrm{td}, J=$ $14.3,7.1,1 \mathrm{H}), 5.50-5.30(\mathrm{~m}, 2 \mathrm{H}), 4.18(\mathrm{tt}, J=11.9,4.2,1 \mathrm{H}), 3.88(\mathrm{~d}, J=11.8,1 \mathrm{H}), 3.74(\mathrm{t}$, $J=11.0,1 \mathrm{H}), 3.50(\mathrm{q}, J=10.0,2 \mathrm{H}), 3.35(\mathrm{~s}, 3 \mathrm{H}), 3.23(\mathrm{t}, J=10.7,1 \mathrm{H}), 2.57(\mathrm{dd}, J=13.2$, $3.7,1 \mathrm{H}), 2.38(\mathrm{t}, J=14.5,1 \mathrm{H}), 2.31(\mathrm{t}, J=13.6,1 \mathrm{H}), 2.19(\mathrm{~d}, J=9.6,1 \mathrm{H}), 2.01(\mathrm{t}, J=12.2$, $1 \mathrm{H}), 1.96-1.20(\mathrm{~m}, 14 \mathrm{H}), 1.17(\mathrm{~d}, J=7.0,3 \mathrm{H}), 1.08-0.97(\mathrm{~m}, 1 \mathrm{H}), 0.86(\mathrm{~d}, J=6.6,6 \mathrm{H}) ;{ }^{13} \mathrm{C}$ NMR (125 MHz, $\left.\mathrm{CDCl}_{3}\right) \delta 169.1,132.8,130.2,75.3,74.2,73.8,73.5,71.2,63.2,57.5,45.4$, 43.1, 43.0, 43.0, 42.9, 42.9, 41.8, 39.1, 35.7, 31.2, 29.9, 28.3, 27.3, 24.3, 22.5, 18.4; HRMS (ESI), calcd for $\mathrm{C}_{25} \mathrm{H}_{41} \mathrm{BrO}_{5} \mathrm{Na}[\mathrm{M}+\mathrm{Na}]^{+}$523.2035, found 523.2026.

\section{Macrocyclic alcohol 31}

To a solution of the macrocyclic bromide $8(5.0 \mathrm{mg}, 0.010 \mathrm{mmol}, 1.0$ equiv) in anhydrous toluene $(0.35 \mathrm{~mL})$ was added cesium acetate $(13.4 \mathrm{mg}, 0.070 \mathrm{mmol}, 7.0$ equiv) and 18 -crown- 6 (18.4 mg, $0.010 \mathrm{mmol}, 1.0$ equiv). This mixture was heated at $110^{\circ} \mathrm{C}$ in a sealed tube for 20 h. After cooling to $23^{\circ} \mathrm{C}$, the mixture was diluted with dichloromethane $(5 \mathrm{~mL})$ and water $(5$ $\mathrm{mL}$ ). The layers were separated and the aqueous layer was extracted with dichloromethane (3 $\times 5 \mathrm{~mL}$ ). The combined organic layers were dried over anhydrous sodium sulfate and concentrated in vacuo. The crude oil was filtered through a silica gel plug (0-60\% ethyl acetate/ hexanes) to provide an oil, upon concentration of the fractions. This oil was dissolved in methanol $(0.5 \mathrm{~mL})$ and potassium carbonate $(1.3 \mathrm{mg}, 0.010 \mathrm{mmol}, 1$ equiv) was added. After $45 \mathrm{~min}$, the mixture was filtered through Celite and the resulting filtrate was concentrated in vacuo. The crude mixture was purified by flash chromatography (20-100\% ethyl acetate/ hexanes) to provide $2.6 \mathrm{mg}$ (60\% over the two steps) of macrocyclic alcohol $\mathbf{3 1}$ as a white solid: $[\alpha]^{23} \mathrm{D}+32.9(c=0.13$, ethanol); IR (thin film) $3444,2957,2925,2855,1738,1262$, $1061,1032 \mathrm{~cm}^{-1} ;{ }^{1} \mathrm{H}$ NMR $\left(600 \mathrm{MHz}, \mathrm{CDCl}_{3}\right) \delta 5.71(\mathrm{td}, J=14.4,7.3,1 \mathrm{H}), 5.44-5.34(\mathrm{~m}$, $2 \mathrm{H}), 4.31(\mathrm{br} \mathrm{s}, 1 \mathrm{H}), 4.17(\mathrm{t}, J=11.4,1 \mathrm{H}), 3.90(\mathrm{~d}, J=11.5,1 \mathrm{H}), 3.73(\mathrm{dt}, J=9.3,3.4,1 \mathrm{H})$, $3.60(\mathrm{t}, J=10.6,1 \mathrm{H}), 3.55(\mathrm{t}, J=10.8,1 \mathrm{H}), 3.36(\mathrm{~s}, 3 \mathrm{H}), 2.54(\mathrm{dd}, J=13.0,3.9,1 \mathrm{H}), 2.45(\mathrm{t}$, $J=13.0,1 \mathrm{H}), 2.32(\mathrm{t}, J=12.9,1 \mathrm{H}), 2.14-1.20(\mathrm{~m}, 16 \mathrm{H}), 1.17(\mathrm{~d}, J=7.1,3 \mathrm{H}), 1.05-0.97(\mathrm{~m}$, $1 \mathrm{H}), 0.86(\mathrm{dd}, J=6.6,1.7,6 \mathrm{H}) ;{ }^{13} \mathrm{C}$ NMR $\left(125 \mathrm{MHz}, \mathrm{CDCl}_{3}\right) \delta 169.9,132.5,130.5,73.9$, 73.7, 70.9, 69.2, 69.1, 65.0, 63.2, 57.5, 43.6, 43.1, 41.8, 39.6, 38.8, 38.7, 35.9, 31.2, 29.9, 28.4, 27.3, 24.3, 22.5, 18.5; ${ }^{1} \mathrm{H}$ NMR (500 MHz, $\left.\mathrm{C}_{5} \mathrm{D}_{5} \mathrm{~N}\right) \delta 6.39(\mathrm{br} \mathrm{s}, 1 \mathrm{H}), 5.84-5.71(\mathrm{~m}, 2 \mathrm{H}), 5.55$ (dd, $J=15.2,6.6,1 \mathrm{H}), 4.64(\mathrm{t}, J=11.6,1 \mathrm{H}), 4.42(\mathrm{br} \mathrm{s}, 1 \mathrm{H}), 4.18(\mathrm{t}, J=11.6,1 \mathrm{H}), 4.06(\mathrm{~d}$, $J=11.8,1 \mathrm{H}), 3.93(\mathrm{t}, J=10.5,1 \mathrm{H}), 3.75(\mathrm{t}, J=10.8,1 \mathrm{H}), 3.37(\mathrm{~s}, 3 \mathrm{H}), 2.68(\mathrm{dd}, J=12.9,3.5$, $1 \mathrm{H}), 2.54-2.45(\mathrm{~m}, 2 \mathrm{H}), 2.11(\mathrm{t}, J=12.9,1 \mathrm{H}), 1.99-1.80(\mathrm{~m}, 4 \mathrm{H}), 1.80-1.40(\mathrm{~m}, 3 \mathrm{H}), 1.40$ -1.15 (m, 7H), 1.15-0.97 (m, 2H), 1.09 (d, $J=7.0,3 \mathrm{H}), 0.79$ (dd, $J=6.5,3 \mathrm{H}), 0.78$ (dd, $J=$ 
6.5, 3H); ${ }^{13} \mathrm{C}$ NMR $\left(125 \mathrm{MHz}, \mathrm{C}_{5} \mathrm{D}_{5} \mathrm{~N}\right) \delta 170.3,132.0,131.5,73.9,73.8,70.9,69.9,69.7$, 63.8, 63.1, 56.7, 44.0, 43.4, 41.8, 39.9, 39.7, 39.5, 35.9, 31.4, 28.3, 27.4, 24.3, 22.3, 22.3, 18.4; HRMS (ESI), calcd for $\mathrm{C}_{25} \mathrm{H}_{42} \mathrm{O}_{6} \mathrm{Na}[\mathrm{M}+\mathrm{Na}]^{+} 461.2879$, found 461.2859.

\section{Leucascandrolide A (1)}

To a solution of $\alpha$-selenyl ester 38 ( $16.0 \mathrm{mg}, 0.025 \mathrm{mmol}, 1.0$ equiv) in anhydrous dichloromethane $(0.5 \mathrm{~mL})$ at $-78{ }^{\circ} \mathrm{C}$ was added titanium tetrachloride $(55.0 \mu \mathrm{L}, 0.055 \mathrm{mmol}$, $1.0 \mathrm{M}, 2.2$ equiv) as a solution in anhydrous dichloromethane, dropwise. The addition of diisopropylethyl amine $(9.6 \mu \mathrm{L}, 0.055 \mathrm{mmol}, 2.2$ equiv) followed and the dark red solution was allowed to stir for one hour. Triphenylphosphine oxide ( $15.3 \mathrm{mg}, 0.055 \mathrm{mmol}, 2.2$ equiv), as a solution in $0.05 \mathrm{~mL}$ anhydrous dichloromethane, was then added. The resultant solution was stirred for one hour then a solution of aldehyde $\mathbf{3 3}(9.1 \mathrm{mg}, 0.038 \mathrm{mmol}, 1.5$ equiv) in 0.05 $\mathrm{mL}$ anhydrous dichloromethane was added. After stirring for one additional hour, saturated aqueous ammonium chloride $(1 \mathrm{~mL})$ was added and the mixture was stirred vigorously and allowed to warm to $23{ }^{\circ} \mathrm{C}$. The mixture was then diluted with dichloromethane $(5 \mathrm{~mL})$ and water $(5 \mathrm{~mL})$ and the layers were separated. The aqueous layer was extracted with dichloromethane $(3 \times 5 \mathrm{~mL})$. The combined organic layers were washed with brine $(1 \times 5 \mathrm{~mL})$, dried over anhydrous sodium sulfate, and concentrated in vacuo. The crude oil was subjected to flash chromatography (10-100\% ethyl acetate/hexanes), which provided $7.0 \mathrm{mg}$ of the starting $\alpha$-selenyl ester $\mathbf{3 8}$ and $15.0 \mathrm{mg}$ of a mixture of the desired aldol product, aldehyde 33, and triphenylphosphine oxide. The latter mixture was redissolved in anhydrous dichloromethane $(0.1 \mathrm{~mL})$ and the resultant solution was cooled to $0{ }^{\circ} \mathrm{C}$. A solution of methanesulfonyl chloride $(12.2 \mu \mathrm{L}, 0.106 \mathrm{mmol}, 6.2$ equiv) and pyridine $(13.7 \mu \mathrm{L}, 0.170 \mathrm{mmol}$, 10 equiv) in anhydrous dichloromethane $(0.1 \mathrm{~mL})$ was added and the mixture was stirred for three hours. Water $(1 \mathrm{~mL})$ was then added and the biphasic mixture was allowed to warm to $23{ }^{\circ} \mathrm{C}$. The mixture was then diluted with dichloromethane $(5 \mathrm{~mL})$ and water $(5 \mathrm{~mL})$ and the layers were separated. The aqueous layer was extracted with dichloromethane $(3 \times 5 \mathrm{~mL})$. The combined organic layers were washed with brine $(1 \times 5 \mathrm{~mL})$, dried over anhydrous sodium sulfate, and concentrated in vacuo. The crude oil was subjected to flash chromatography (5-60\% ethyl acetate/hexanes), which provided $4.0 \mathrm{mg}$ (40\%, over the two steps) of leucascandrolide A as a clear, colorless oil: $[\alpha]^{23}{ }_{\mathrm{D}}+39.5(c=0.32$, ethanol); IR (thin film) 3336, 2954, 2927, 2870, 1716, 1646, 1274, 1168, $1081 \mathrm{~cm}^{-1} ;{ }^{1} \mathrm{H}$ NMR $\left(500 \mathrm{MHz}, \mathrm{CDCl}_{3}\right) \delta$ $7.40(\mathrm{~s}, 1 \mathrm{H}), 6.34(\mathrm{dt}, J=14.7,7.7,1 \mathrm{H}), 6.31(\mathrm{~d}, J=12.7,1 \mathrm{H}), 6.10(\mathrm{dt}, J=12.7,6.6,1 \mathrm{H})$, $5.91(\mathrm{~d}, J=11.5,1 \mathrm{H}), 5.75-5.67(\mathrm{~m}, 1 \mathrm{H}), 5.57-5.47(\mathrm{~m}, 1 \mathrm{H}), 5.40-5.33(\mathrm{~m}, 2 \mathrm{H}), 5.27(\mathrm{t}, J=$ 2.6, $1 \mathrm{H}), 4.36-4.26(\mathrm{~m}, 2 \mathrm{H}), 4.02(\mathrm{t}, J=11.3,1 \mathrm{H}), 3.90(\mathrm{~d}, J=11.9,1 \mathrm{H}), 3.69(\mathrm{~s}, 3 \mathrm{H}), 3.62$ $-3.51(\mathrm{~m}, 3 \mathrm{H}), 3.36(\mathrm{~s}, 3 \mathrm{H}), 3.11-3.00(\mathrm{~m}, 2 \mathrm{H}), 2.74(\mathrm{t}, J=7.2,2 \mathrm{H}), 2.60-2.50(\mathrm{~m}, 1 \mathrm{H}), 2.47$ $-2.27(\mathrm{~m}, 2 \mathrm{H}), 2.00-1.82(\mathrm{~m}, 4 \mathrm{H}), 1.80-1.48(\mathrm{~m}, 7 \mathrm{H}), 1.36-1.20(\mathrm{~m}, 4 \mathrm{H}), 1.17(\mathrm{~d}, J=7.1$, $3 \mathrm{H}), 1.07-0.99(\mathrm{~m}, 1 \mathrm{H}), 0.86(\mathrm{~d}, J=6.6,6 \mathrm{H}) ;{ }^{13} \mathrm{C} \mathrm{NMR}\left(125 \mathrm{MHz}, \mathrm{CDCl}_{3}\right) \delta 169.6,165.5$, 160.3, 157.4, 149.5, 141.3, 136.6, 134.1, 132.6, 130.3, 120.9, 116.9, 73.9, 73.5, 71.1, 70.2, 69.8, 67.5, 63.3, 57.5, 52.4, 43.5, 42.5, 41.8, 39.6, 39.4, 35.8, 35.7, 31.2, 29.9, 27.9, 27.4, 25.9, 24.5, 22.5, 18.5; HRMS (ESI), calcd for $\mathrm{C}_{38} \mathrm{H}_{56} \mathrm{O}_{10} \mathrm{~N}_{2} \mathrm{Na}[\mathrm{M}+\mathrm{Na}]^{+} 723.3832$, found 723.3845 .

\section{Supporting Information Available}

Refer to Web version on PubMed Central for supplementary material.

\section{Acknowledgements}

This work was supported by the National Cancer Institute (CA-081635). 


\section{References}

1. D'Ambrosio M, Guerriero A, Debitus C, Pietra F. Helv Chim Acta 1996;79:51-60.

2. This particular class of sponges typically produces compounds consisting of 2-amino imidazoles. See reference ${ }^{1}$.

3. Hornberger KR, Hamblett CL, Leighton JL. J Am Chem Soc 2000;122:12894-12895.

4. a Paterson I, Tudge M. Angew Chem, Int Ed 2003;42:343-347. b Paterson I, Tudge M. Tetrahedron 2003;59:6833-6849.

5. a Wang Y, Janjic J, Kozmin SA. Pure Appl Chem 2005;77:1161-1169. b Wang Y, Janjic J, Kozmin SA. J Am Chem Soc 2002;124:13670-13671. [PubMed: 12431085]

6. a Su Q, Dakin LA, Panek JS. J Org Chem 2006;72:2-24. [PubMed: 17194076] b Su Q, Panek JS. Angew Chem, Int Ed 2005;44:1223-1224.

7. a Fettes A, Carreira EM. J Org Chem 2003;68:9274-9283. [PubMed: 14629147] b Fettes A, Carreira EM. Angew Chem, Int Ed 2002;41:4098-4101.

8. Crimmins MT, Siliphaivanh P. Org Lett 2003;5:4641-4644. [PubMed: 14627404]

9. Wipf P, Reeves JT. Chem Commun 2002:2066-2067.

10. a Williams DR, Plummer SV, Patnaik S. Angew Chem, Int Ed 2003;42:3934-3938. b Williams DR, Patnaik S, Plummer SV. Org Lett 2003;5:5035-5038. [PubMed: 14682758]

11. Kopecky DJ, Rychnovsky SD. J Am Chem Soc 2001;123:8420-8421. [PubMed: 11516301]

12. Patterson B, Marumoto S, Rychnovsky SD. Org Lett 2003;5:3163-3166. [PubMed: 12917007]

13. At this stage, we planned to use the combined procedures of Leighton and Kozmin (cf. ref. ${ }^{3}$ and ${ }^{5}$ ) to access the side chain.

14. Preparation of 12a: Bennett F, Knight DW, Fenton G. J Chem Soc Perkin Trans 1 1991:133140.Preparation of 12b: Keck GE, Truong AP. Org Lett 2005;7:2153-2156. [PubMed: 15901157]

15. La Cruz TE, Rychnovsky SD. Org Lett 2005;7:1873-1875. [PubMed: 15844928]

16. Watanabe WH, Conlon LE. J Am Chem Soc 1957;79:2828-2833.

17. For a recent comprehensive review, see: Grubbs RH. Tetrahedron 2004;60:7117-7140.

18. Louie J, Bielawski CW, Grubbs RH. J Am Chem Soc 2001;123:11312-11313. [PubMed: 11697983]

19. Ulman M, Grubbs RH. J Org Chem 1999;64:7202-7207.

20. a Dahanukar VH, Rychnovsky SD. J Org Chem 1996;61:8317-8320. [PubMed: 11667826] b Kopecky DJ, Rychnovsky SD. J Org Chem 2000;65:191-198. [PubMed: 10813915] c Kopecky DJ, Rychnovsky SD. Org Synth 2003;80:177.

21. Kourouli T, Kefalas P, Ragoussis N, Ragoussis V. J Org Chem 2002;67:4615-4618. [PubMed: 12076169]

22. A similar approach was used by Paterson to assemble the C11-C15 THP ring (ref 4).

23. Deslongchamps, P. Stereoelectronic Effects in Organic Chemistry. Pergamon; New York: 1983. p. 209-221. b Stevens RV, Lee AWM. J Am Chem Soc 1979;101:7032-7035. c Stevens RV. Acc Chem Res 1984;17:289-296. d Lewis MD, Cha JK, Kishi Y. J Am Chem Soc 1982;104:4976-4978.

24. a Corey EJ, Bakshi RK, Shibata S, Chen CP, Singh VK. J Am Chem Soc 1987;109:7925-7926. b Corey EJ, Helal CJ. Angew Chem Int Ed 1998;37:1986-2012.

25. Synthesis of the pyrrolidinol ligands: Nikolic NA, Beak P. Org Synth, Coll 9:391-397.b Xavier LC, Mohan JJ, Mathre DJ, Thompson AS, Carroll JD, Corley EG, Desmond R. Org Synth, Coll 9:676689.Synthesis of the catalyst: Mathre DJ, Jones TK, Xavier LC, Blacklock TJ, Reamer RA, Mohan JJ, Turner Jones ET, Hoogsteen K, Baum MW, Grabowski EJJ. J Org Chem 1991;56:751-762. d Mathre DJ, Thompson AS, Douglas AW, Hoogsteen K, Carroll JD, Corley EG, Grabowski EJJ. J Org Chem 1993;58:2880-2888.

26. Jung ME, Ho D, Chu HV. Org Lett 2005;7:1649-1651. [PubMed: 15816774]

27. Jasti R, Anderson CD, Rychnovsky SD. J Am Chem Soc 2005;127:9939-9945. [PubMed: 15998101]

28. Evans DA, Dart MJ, Duffy JL, Yang MG. J Am Chem Soc 1996;118:4322-4343.

29. Patterson, BD. Ph D thesis. University of California-Irvine; Irvine, CA: 2004.

30. a Kraus GA, Taschner MJ. J Org Chem 1980;45:1175-1176. b Lindgren BO, Nilsson T. Acta Chem Scand 1973;27:888-890. c Bal BS, Childers WE Jr, Pinnick HW. Tetrahedron 1981;37:2091-2096. 
31. In many syntheses of leucascandrolide A, a similar two-step oxidation is performed: see references $4,9,10$, and 11 .

32. Still WC, Gennari C. Tetrahedron Lett 1983;24:4405-4408.

33. a Kruizinga WH, Kellogg RM. J Am Chem Soc 1981;103:5183-5189.Burch, JD. PhD thesis. Harvard University; Cambridge, MA: 2005.

34. Cesium carbonate is often used as a base in Horner-Emmons-Wadsworth reactions and presumably decomposition occurs via deprotonation of an $\alpha$-proton: Yamanoi T, Akiyama T, Ishida E, Abe H, Amemiya M, Inazu T. Chem Lett 1989:335-337.Bloch R, Seck M. Tetrahedron Lett 1987;28:58195820.

35. Nakamura S, Hayakawa T, Nishi T, Watanabe Y, Toru T. Tetrahedron 2001:6703-6711.

36. This reaction was not optimized due to the lack of the aldehyde coupling partner at the end of the total synthesis. The unreacted starting material was recovered from the reaction, which shows that optimization should be possible.

37. Bromoether intermediates have been identified in low temperature NMR studies on simple Prins cyclization systems, and were found to be major components in solution (ref. 27).

38. Alder RW, Harvey JN, Oakley MT. J Am Chem Soc 2002;124:4960-4961. [PubMed: 11982351]

39. Jasti R, Vitale J, Rychnovsky SD. J Am Chem Soc 2004;126:9904-9905. [PubMed: 15303848]

40. Ward DE, Gai Y, Kaller BF. J Org Chem 1995;60:7830-7836.

41. Jasti R, Rychnovsky SD. J Am Chem Soc 2006;128:13640-13648. [PubMed: 17031979]

42. Scholl M, Ding S, Lee CW, Grubbs RH. Org Lett 1999;1:953. [PubMed: 10823227]

43. See the supporting information for more details on the preparation of this Lewis acid. 


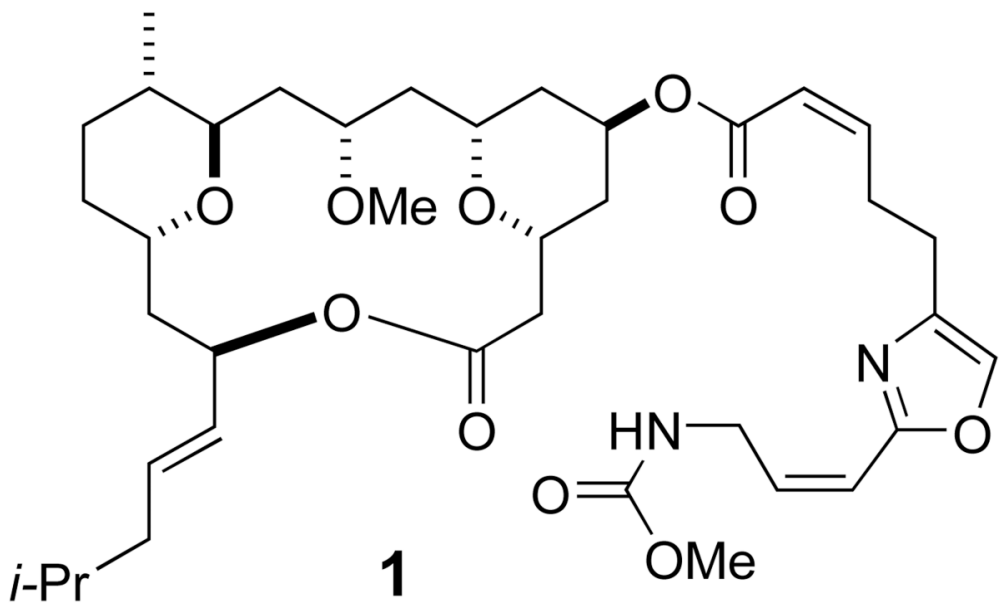

Figure 1.

Leucascandrolide A. 

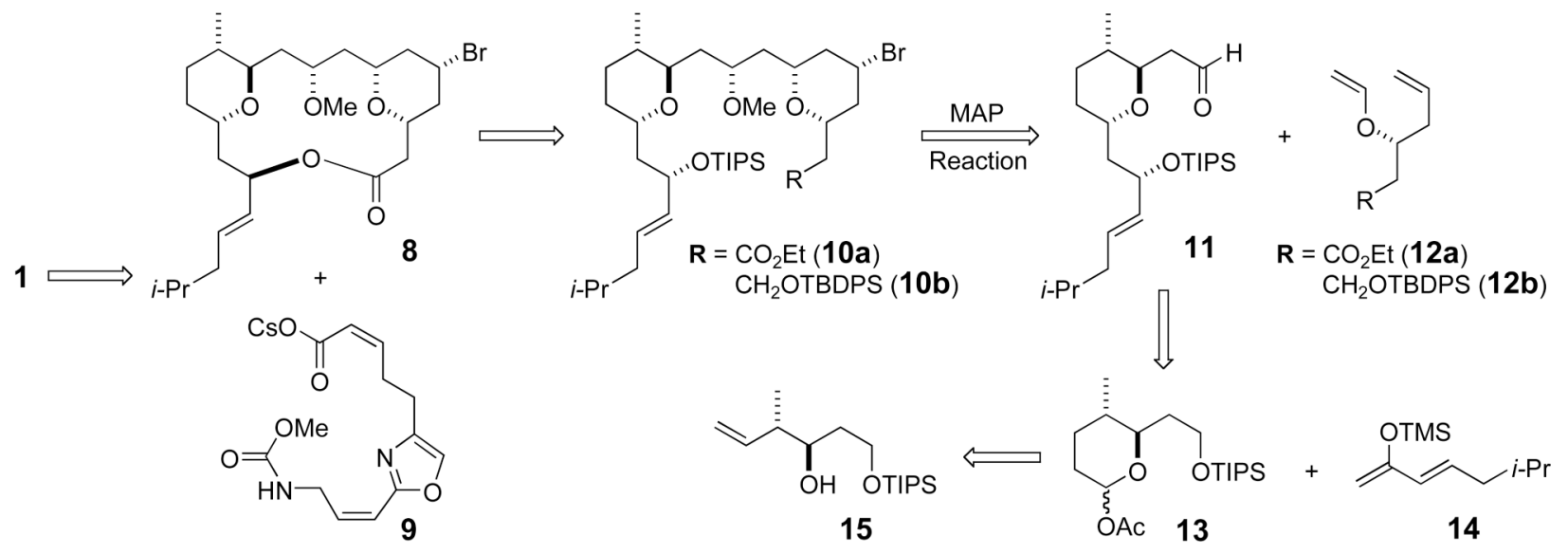

Figure 2.

Second generation retrosynthesis of leucascandrolide A. 

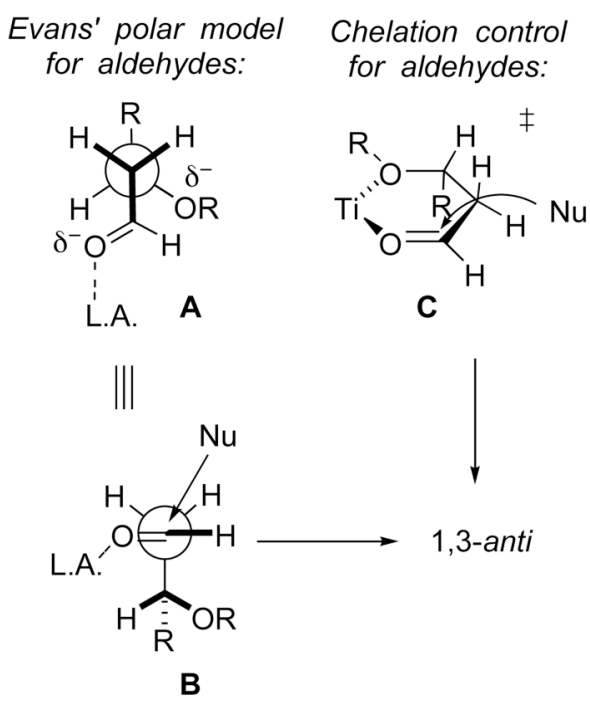

C

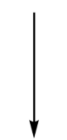

1,3-anti
Polar models available for the acetal system:
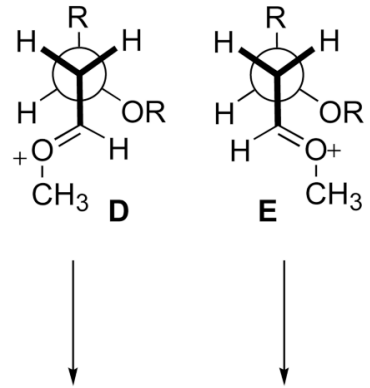

1,3-anti 1,3-syn

Figure 3.

Rationale for the OH/OMe selectivity of MAP reactions. 

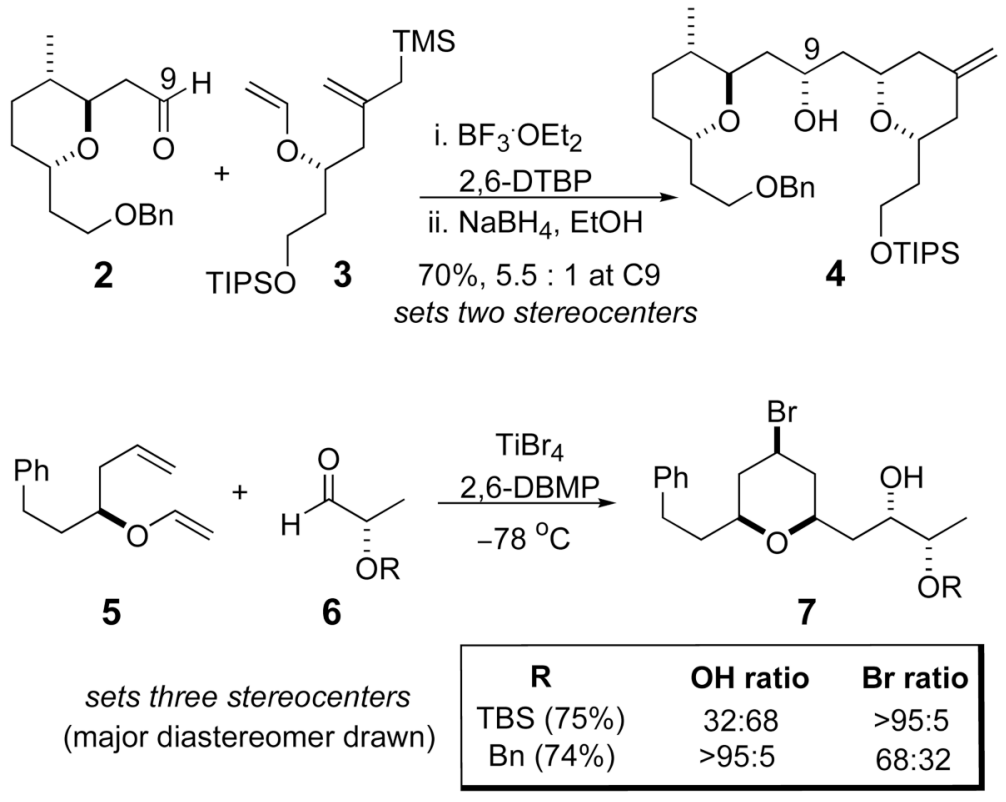

Scheme 1.

Two variants of the Mukaiyama aldol-Prins reactions. 


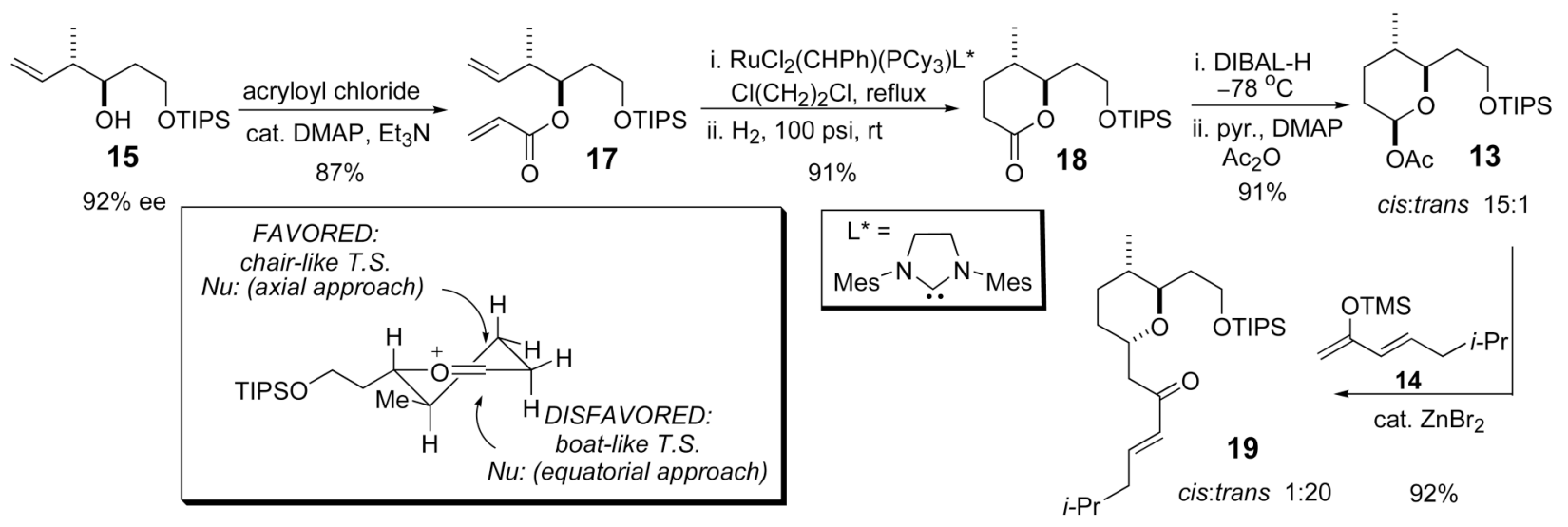

Scheme 2.

Synthesis of the 2,6-trans THP. 


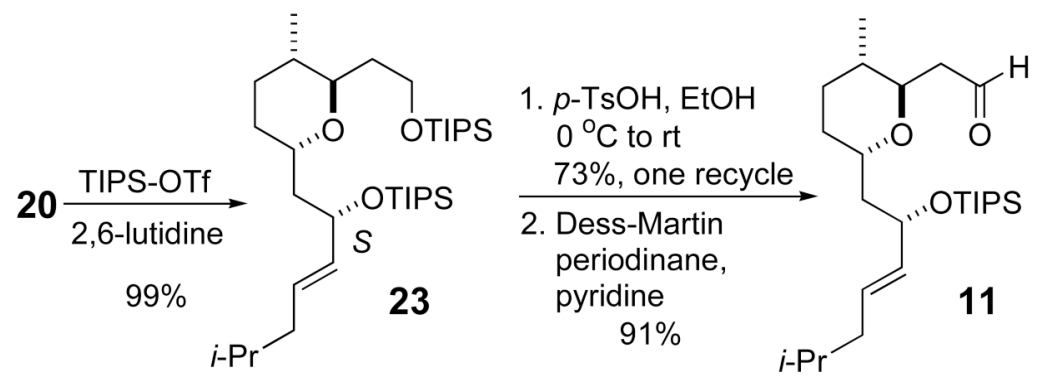

Scheme 3.

Completion of the aldehyde MAP coupling partner. 

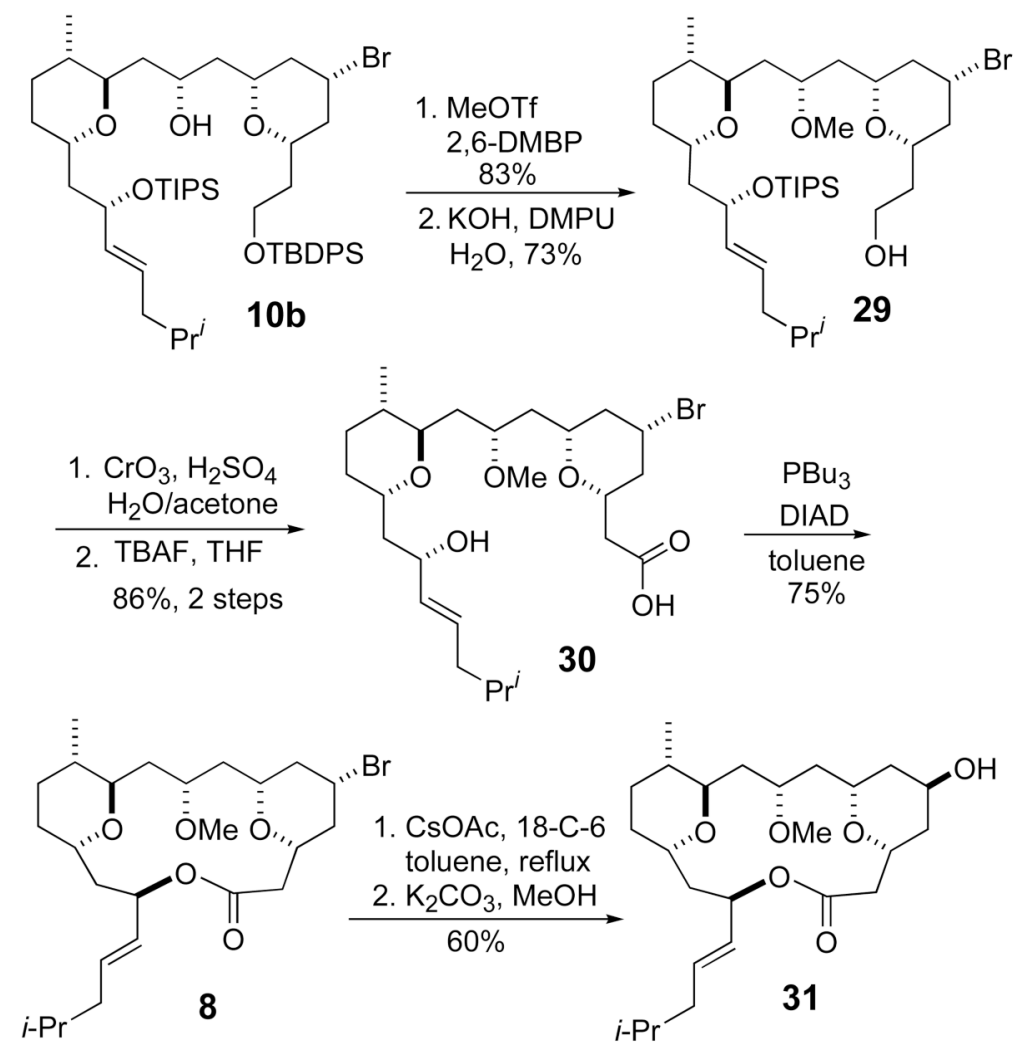

Scheme 4.

Completion of a formal synthesis. 


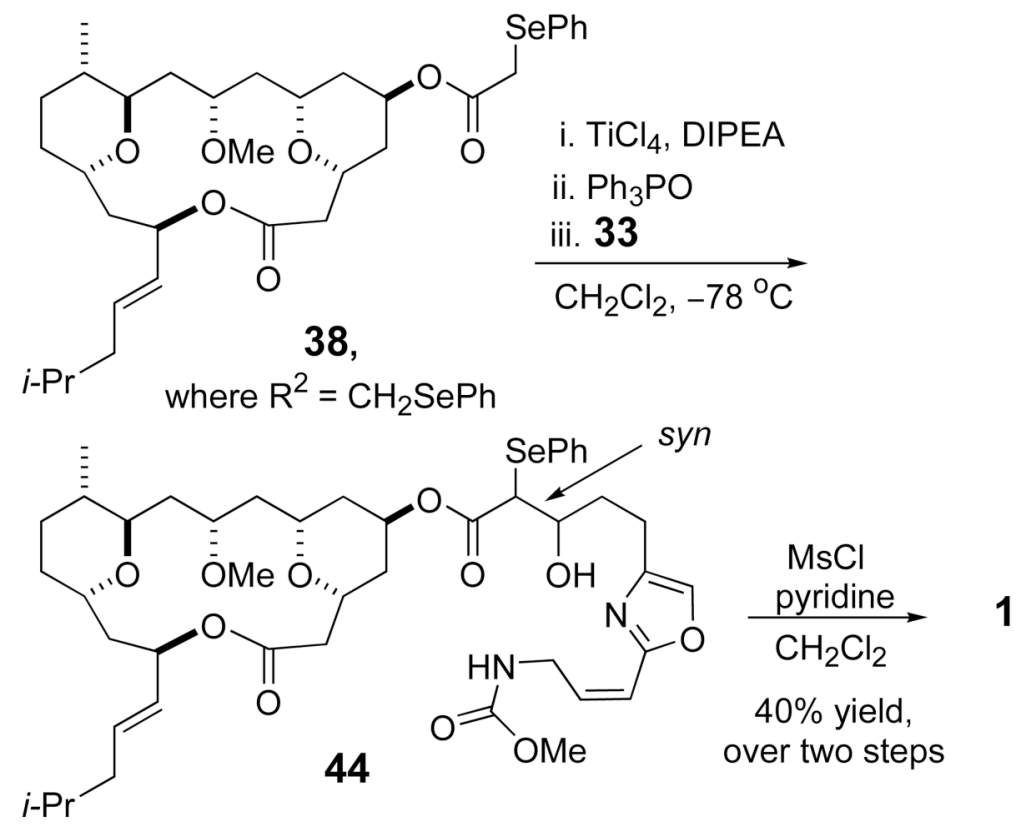

Scheme 5 .

Completion of the total synthesis by aldol reaction and dehydroselenation. 


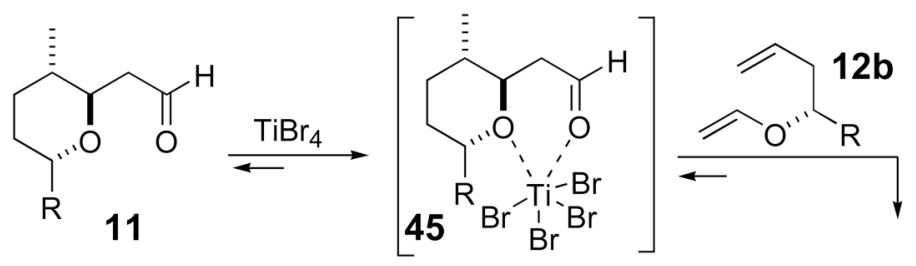

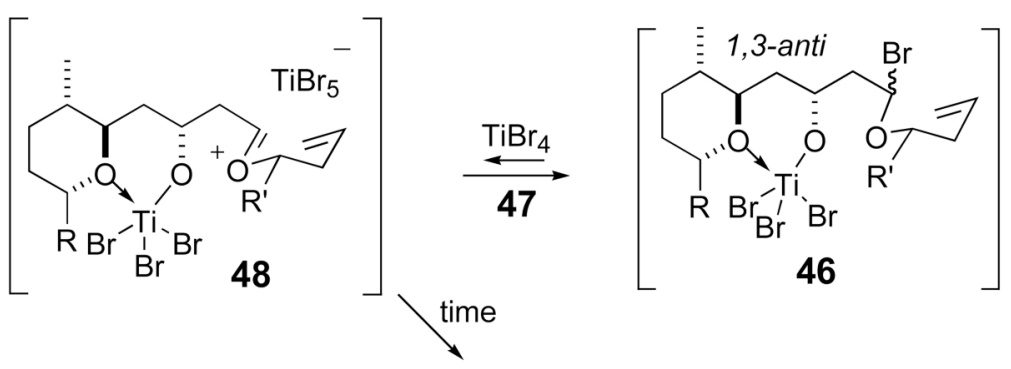

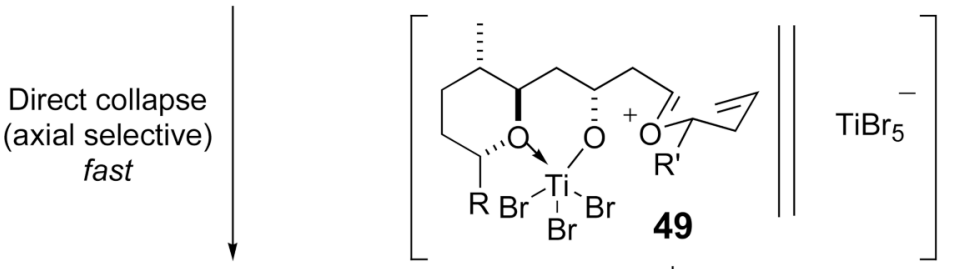
$\downarrow$ equatorial selective

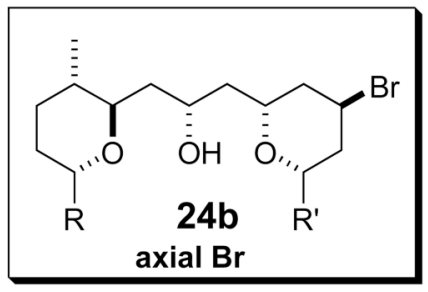

$1.0: 1.3$

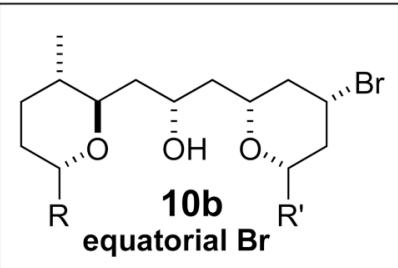

Note: $\mathrm{TiBr}_{4}$ and not the mixed Lewis acid system which was actually used for the synthesis was illustrated for simplicity.

Scheme 6.

Mechanistic rationale: Aldehyde MAP reactions. 


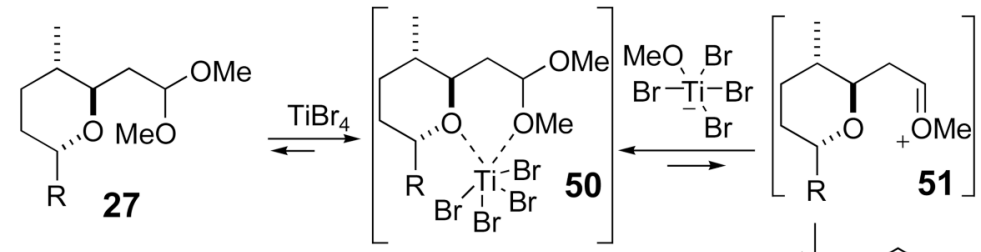<smiles>[R20]C(C/C=C\C)[O+]=CC</smiles><smiles>C1CCCCCC1</smiles>

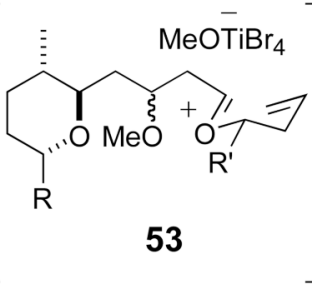

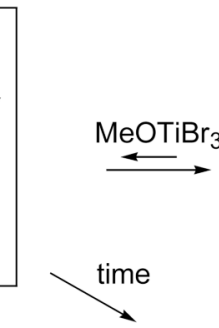

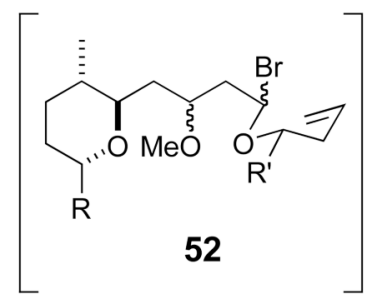
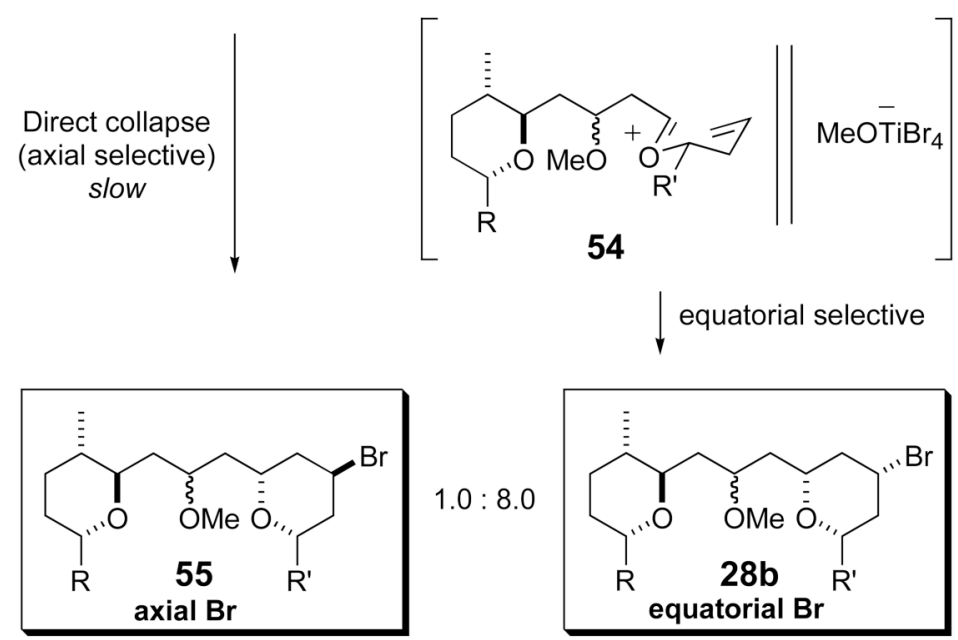

$1.0: 8.0$

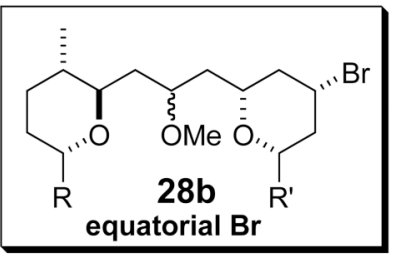

Scheme 7.

Mechanistic rationale: Acetal MAP reactions. 
Table 1

1,2-Reduction of the unsaturated ketone 19

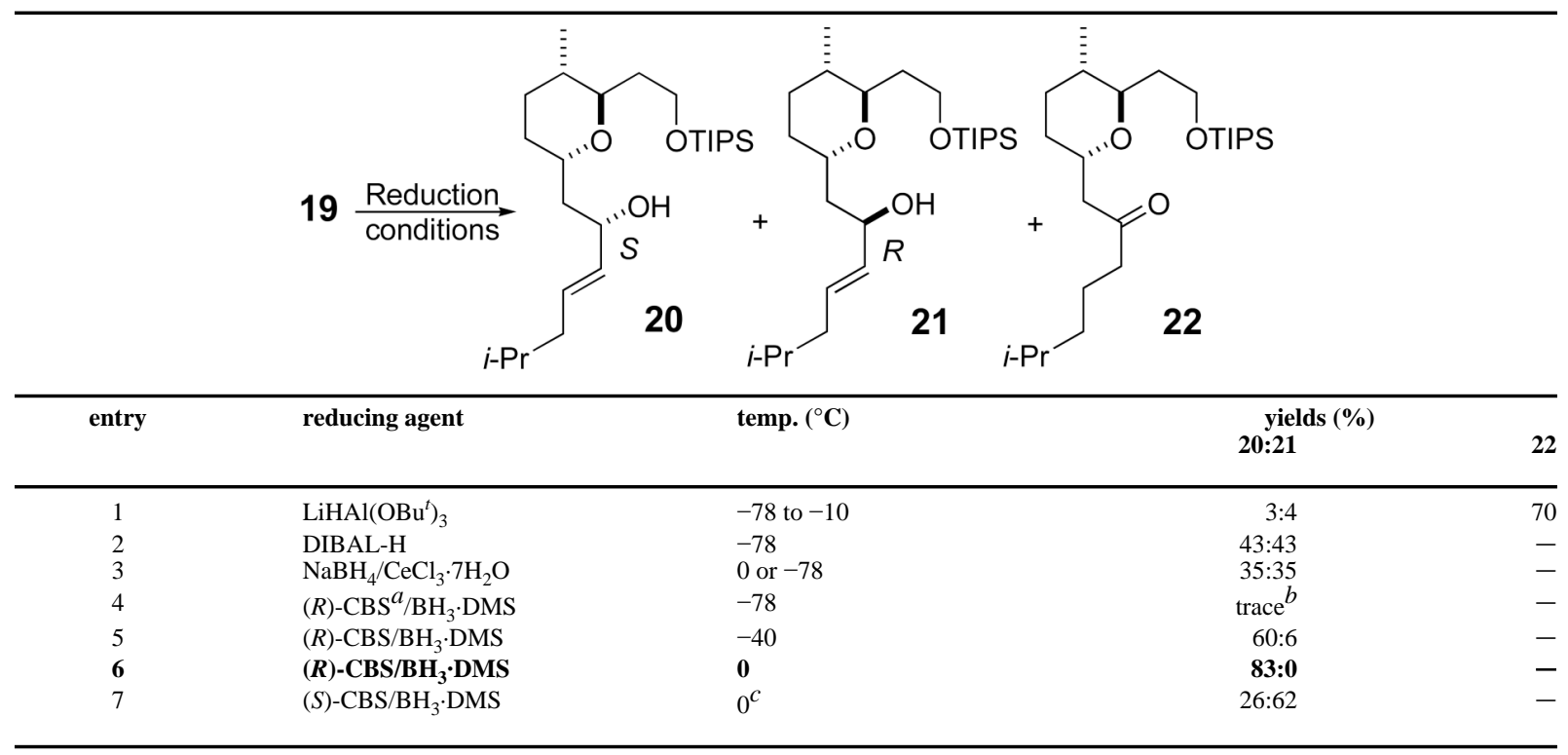

${ }^{a}$ All CBS catalysts were freshly prepared according to the reported procedure (ref. 25).

${ }^{b}$ Starting ketone recovered.

${ }^{c}$ Lower temperatures provided lower conversions and less selectivity. 


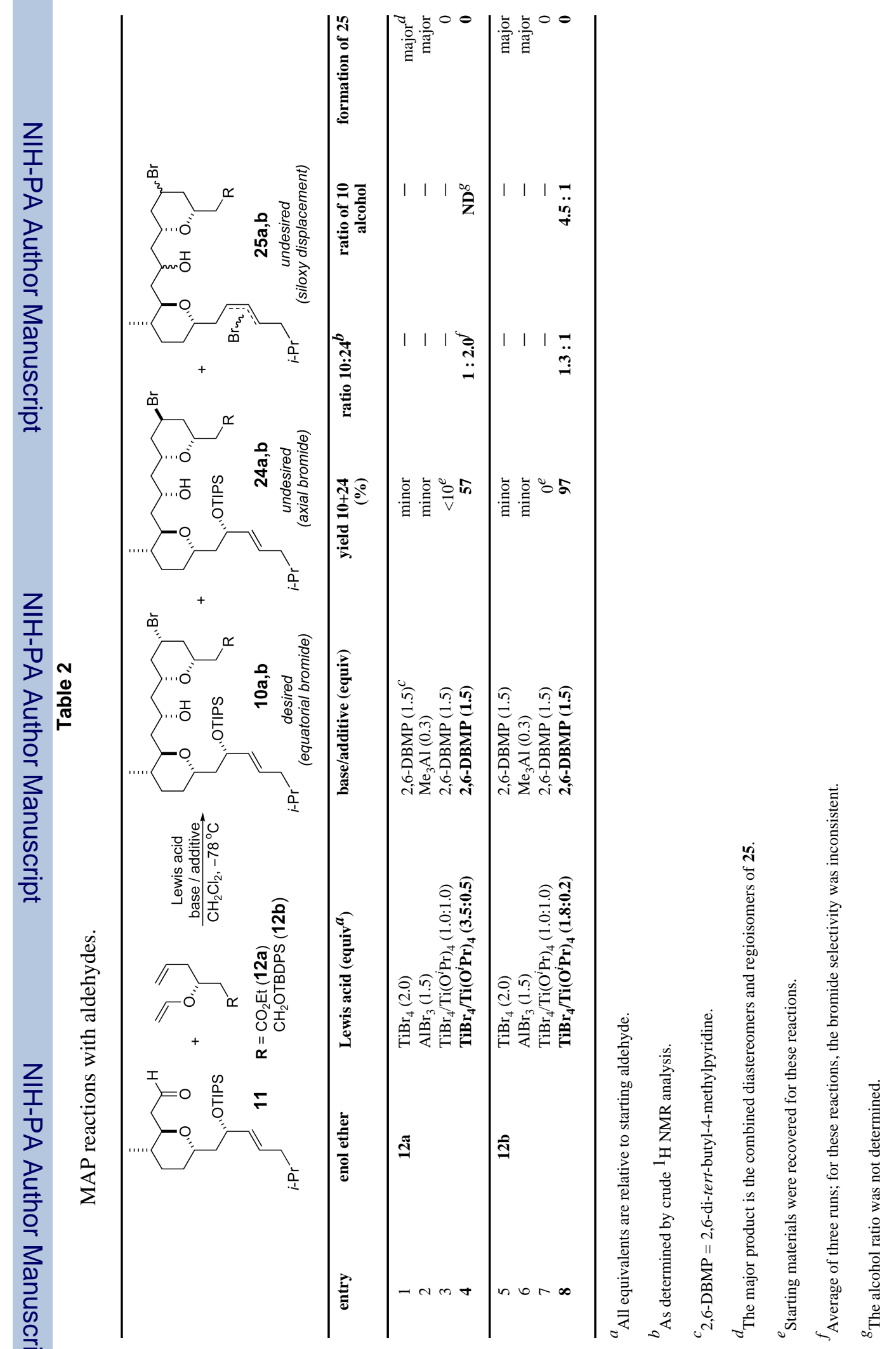




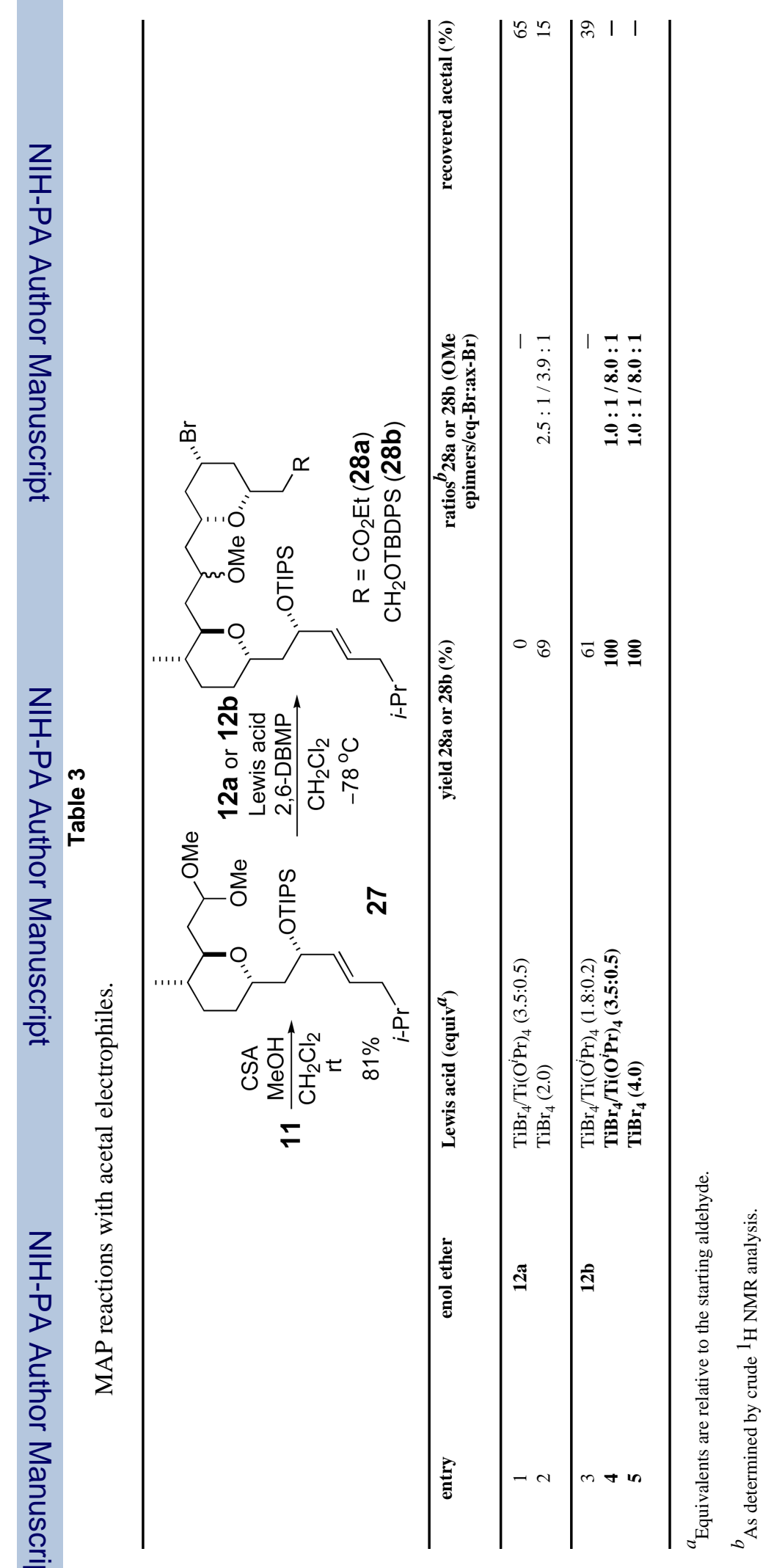

J Org Chem. Author manuscript; available in PMC 2008 August 9. 
Van Orden et al.

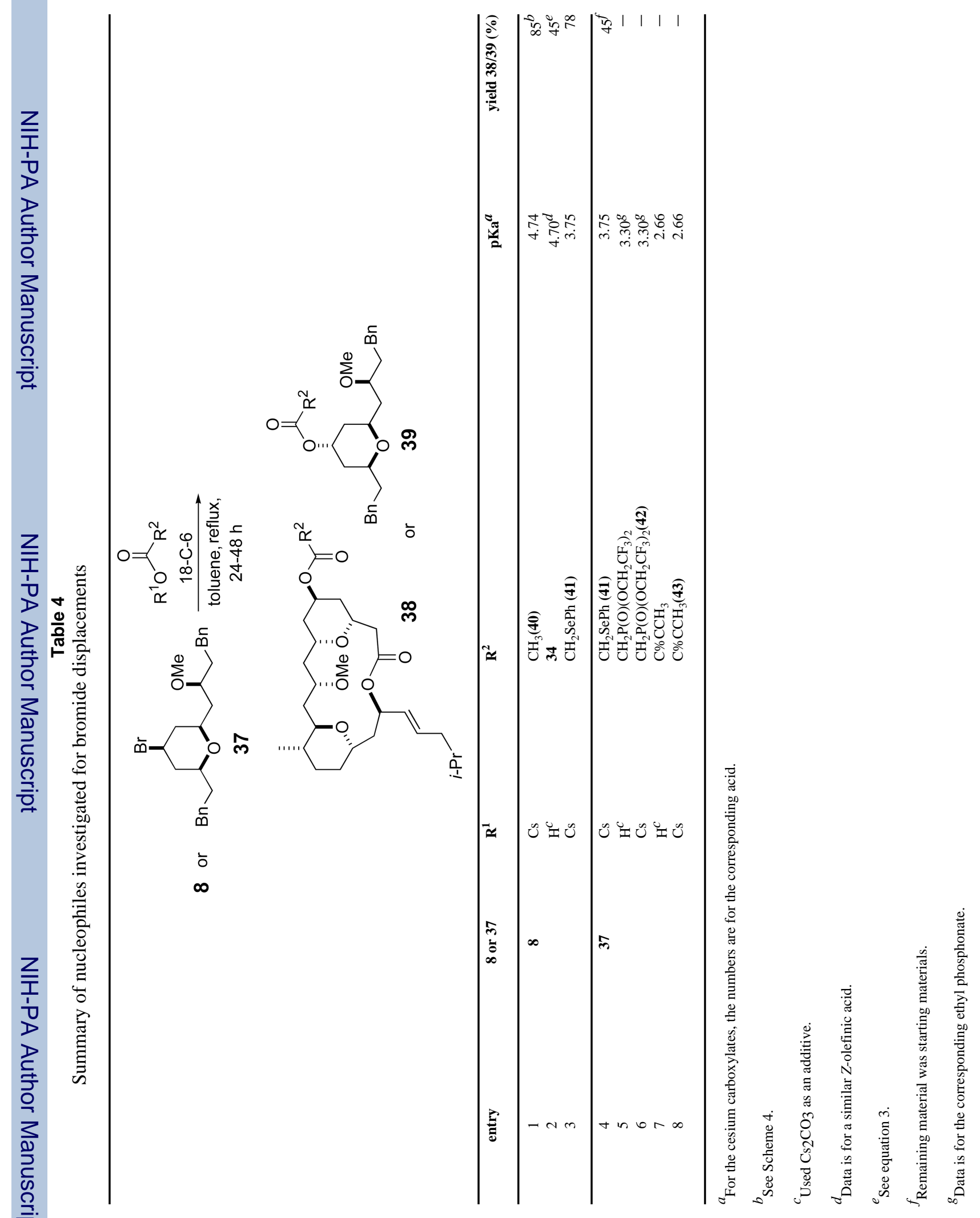

J Org Chem. Author manuscript; available in PMC 2008 August 9. 